\title{
Sweden: 2008 Article IV Consultation-Staff Report; Staff Statement; Public Information Notice on the Executive Board Discussion; and Statement by the Executive Director for Sweden
}

Under Article IV of the IMF's Articles of Agreement, the IMF holds bilateral discussions with members, usually every year. In the context of the 2008 Article IV consultation with Sweden, the following documents have been released and are included in this package:

- $\quad$ The staff report for the 2008 Article IV consultation, prepared by a staff team of the IMF, following discussions that ended on June 3, 2008, with the officials of Sweden on economic developments and policies. Based on information available at the time of these discussions, the staff report was completed on July 10, 2008. The views expressed in the staff report are those of the staff team and do not necessarily reflect the views of the Executive Board of the IMF.

- $\quad$ A staff statement of August 1, 2008, updating information on recent developments.

- $\quad$ A Public Information Notice (PIN) summarizing the views of the Executive Board as expressed during its August 1,2008, discussion of the staff report that concluded the Article IV consultation.

- A statement by the Executive Director for Sweden.

The policy of publication of staff reports and other documents allows for the deletion of market-sensitive information.

Copies of this report are available to the public from

International Monetary Fund $\bullet$ Publication Services

$70019^{\text {th }}$ Street, N.W. $\bullet$ Washington, D.C. 20431

Telephone: (202) 623-7430 • Telefax: (202) 623-7201

E-mail: publications@imf.org •Internet: http://www.imf.org

Price: $\$ 18.00$ a copy

\section{International Monetary Fund Washington, D.C.}





\section{INTERNATIONAL MONETARY FUND}

\section{SWEDEN}

\section{Staff Report for the 2008 Article IV Consultation}

Prepared by the Staff Representatives for the 2008 Consultation with Sweden

Approved by Alessandro Leipold and Adnan Mazarei

July 10, 2008

\section{Executive Summary}

Developments. After robust expansion in 2004-06, growth slowed to 2.7 percent in 2007 with capacity constraints and external uncertainties. Employment growth has been strong, wages have accelerated, and labor productivity has slowed. Inflation picked up; but the fiscal and external current account surpluses remain high. Banks have been resilient to global financial turmoil so far, but vulnerabilities are rising with large regional exposure.

Outlook. The economy is expected to slow below potential in 2008, with a recovery beginning in 2009. Medium-term potential growth is projected to ease to $2-2 \frac{1}{4}$ percent.

Financial sector. While bank risk profiles are increasing, interlocutors were confident that capital buffers are sufficient to absorb stress, should it come- the staff still sees risks. Sweden's bank resolution framework is deficient and needs to be updated and strengthened as a priority. The authorities are working on strengthening cross-border supervisory coordination.

Exchange rate. The krona reflects market forces, but is below its estimated mediumterm value, and hence is expected to appreciate gradually. Competitiveness is strong.

Monetary Policy. The Riksbank has raised the policy rate by 2.75 ppts since 2006 to roughly neutral. Policy should be biased up until inflation expectations drop.

Fiscal Policy. The balance exceeds the 1-percent-of-GDP surplus rule over the cycle. The 2008 budget reduces taxes and welfare benefits to sharpen incentives to work, and seeks to privatize some public enterprises. The staff agrees that the 2009 budget has room to support domestic demand and foster supply improvements. Increasing labor participation to support the welfare state is well taken, given population aging. 


\section{Contents}

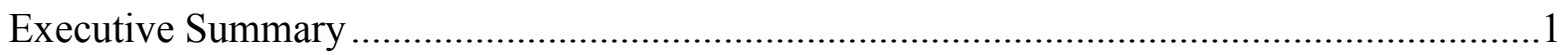

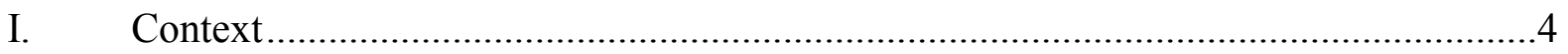

II. Recent Developments ..................................................................................

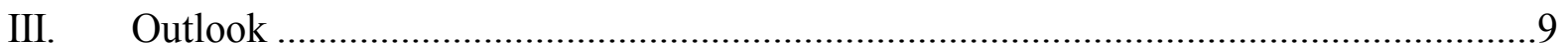

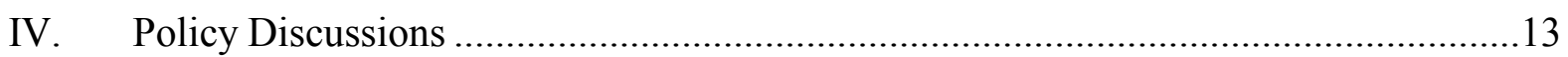

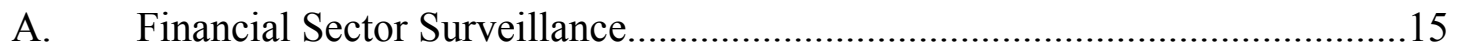

B. Exchange Rate Surveillance..................................................................21

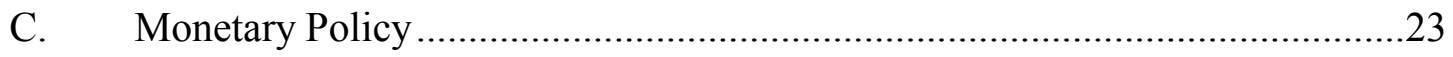

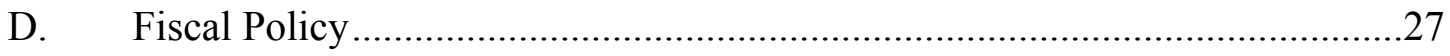

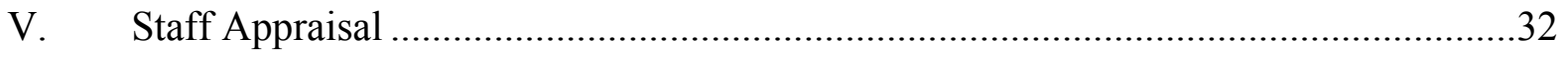

\section{Text Boxes}

1. Default Dependencies and Bank Stabilty............................................................. 19

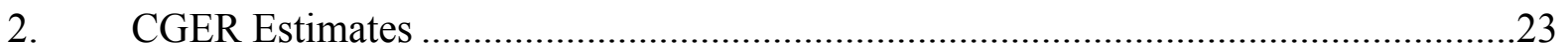

3. Fiscal Steps to Boost Labor Supply ...................................................................29

4. A Preliminary Public Sector Balance Sheet ........................................................ 31

\section{Figures}

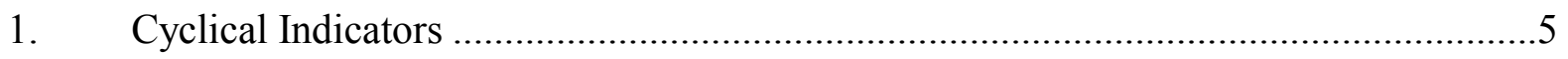

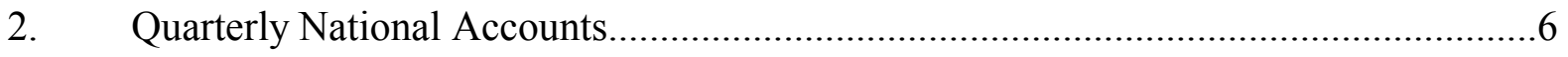

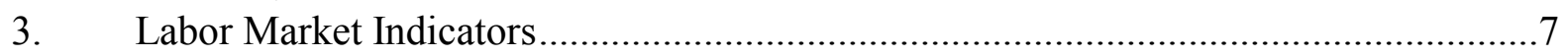

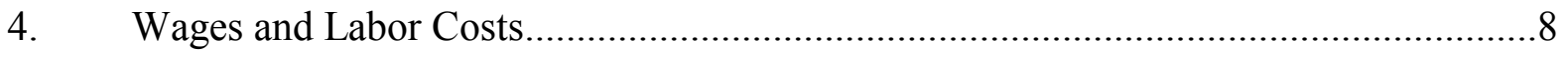

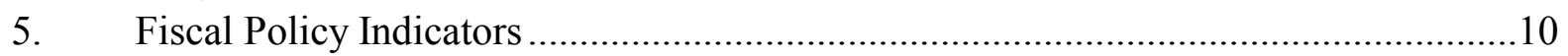

6. Balance of Payments and International Investment Position .....................................11

7. Consumer and Business Confidence Indicators ...................................................... 12

8. Demographic Indicators and Assumptions ............................................................. 14

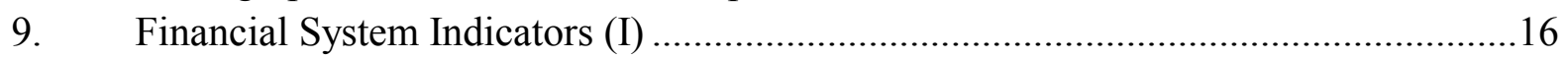

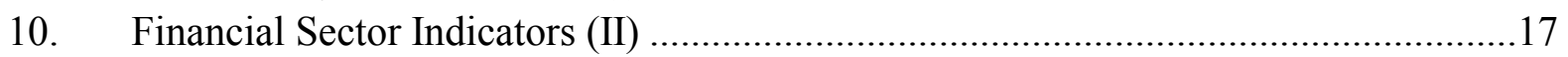

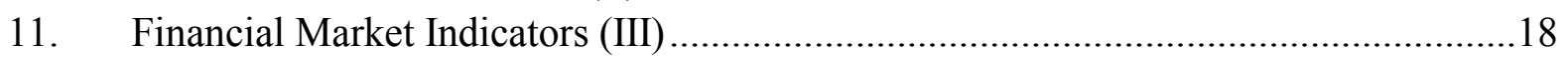

12. Real Effective Exchange Rate Developments .......................................................22

13. Inflation Forecasts and Expectations ..................................................................24

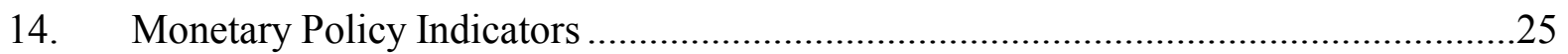

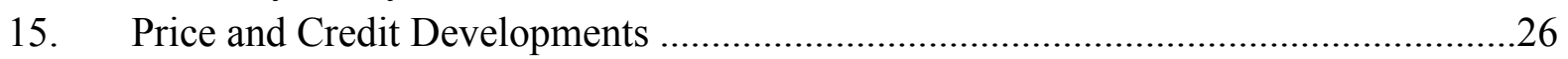

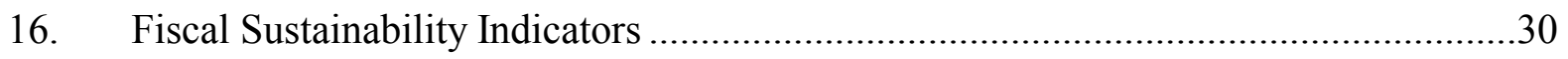




\section{Tables}

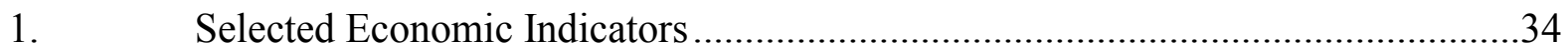

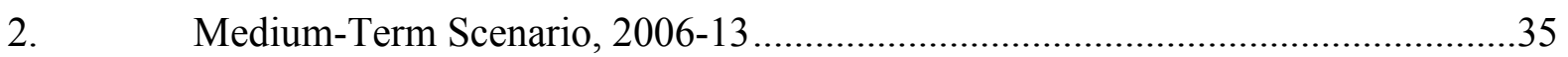

3. Financial System Structure, 2002-07 ……….....................................................

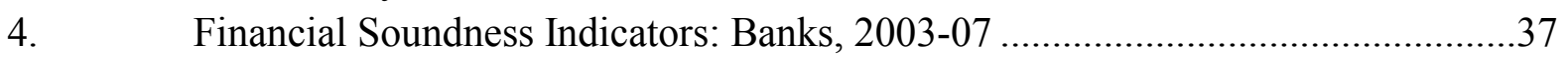

5. $\quad$ Financial Soundness Indicators: Non-Banks, 2003-07 .........................................38

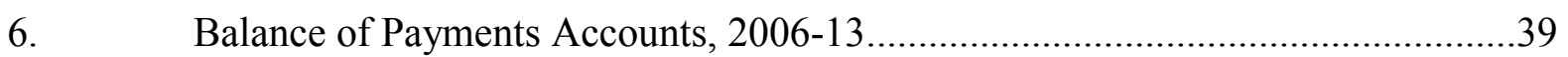

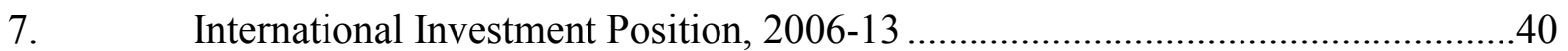

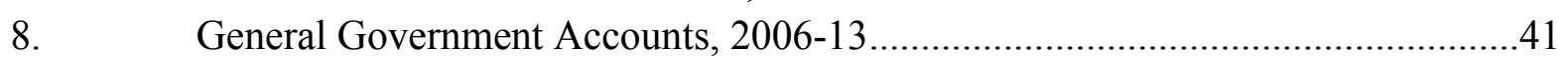

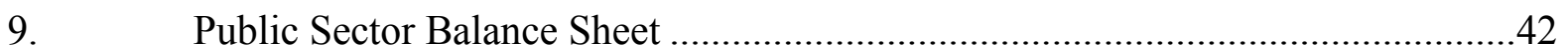

\section{Appendices}

I. Fund Relations 


\section{Context}

1. The economy has performed well, reaching the peak of two recoveries-the business cycle and a decade-long structural recovery following the banking crisis and sharp downturn in the early 1990s. A structural recovery extending far beyond the business cycle has also been observed in other industrial countries following a crisis - the Netherlands after its "Dutch disease" in 1980-82; Germany after the unification cost blowout in 1991-95; Finland after its banking crisis in the 1990s. Activity is now slowing with the two recoveries easing, and demographics reducing potential growth.

2. A center-right government took office in 2006, following three terms of the labor party. The government is boosting labor participation and reducing reliance on the welfare state. The reforms are politically sensitive, and support in the polls has declined somewhat.

\section{Swedish banks have been resilient to global financial turmoil, but risks are} rising. Share prices have dropped compared to Nordic indices, and average CDS spreads have risen, reflecting repricing of risk and weakening growth in the Baltics. Vulnerabilities have been mitigated by strong domestic economic conditions so far.

\section{RECENT DEVELOPMENTS}

4. Activity is moderating. Industrial production is slowing (Figure 1) (Table 1). The manufacturing PMI declined from 60 pts in 2006 to 50. Construction is also softening, after strong growth. Exports benefited from sound competitiveness and strong foreign demand, but euro-area and US slowing is causing a deceleration.

5. Private consumption growth has been relatively smooth. Employment and wages have picked up, and disposable income has benefited from tax cuts. However, recent global financial turmoil has hit confidence and consumption slowed into 2008 (Figure 2).

6. Investment expanded rapidly in 2004-07. Besides construction, Sweden has invested to meet global demand for high value-added products in telecom, biomedicine, and machinery. The competitive krona supported investment. Capacity use was high.

7. The labor market performed well. Employment growth reached 2 percent a year (Figure 3). Supply increased with a larger working-age population, immigration, and higher participation. Unemployment declined from 8 percent in 2005 to 6 percent in early 2008 .

8. Tight capacity boosted prices and wages. Inflation increased from $1 / 2$ percent in 2005 to 4 percent in May 2008. Energy and food prices boosted the headline, but the core rate also rose to 2.9 percent. Wages firmed up, and the Riksbank is monitoring second round effects. ULCs increased when labor productivity fell at the peak of the labor cycle (Figure 4). 
Figure 1. Sweden--Cyclical Indicators suggest growth is slowing

Industrial production is coming off a peak...

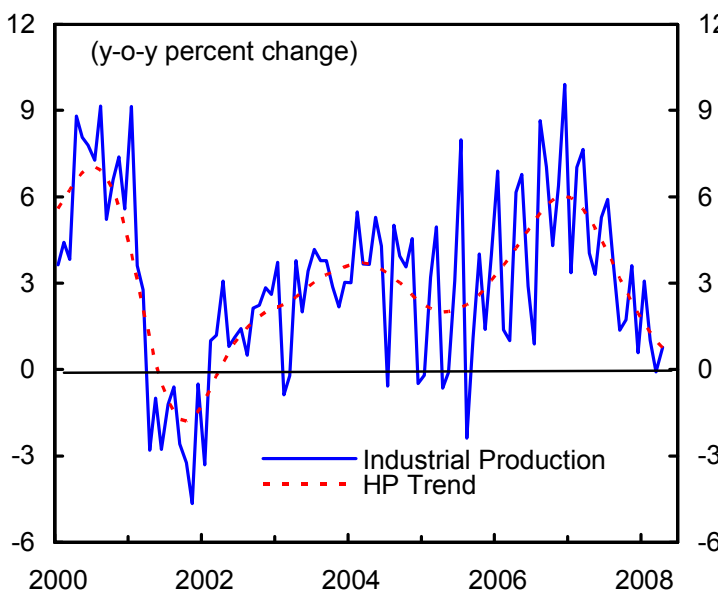

Retail sales growth has declined.

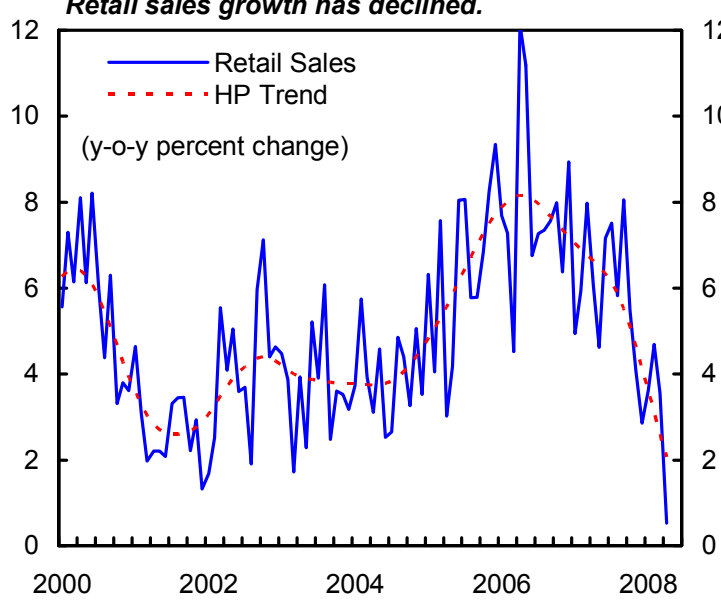

Housing construction is leveling off.

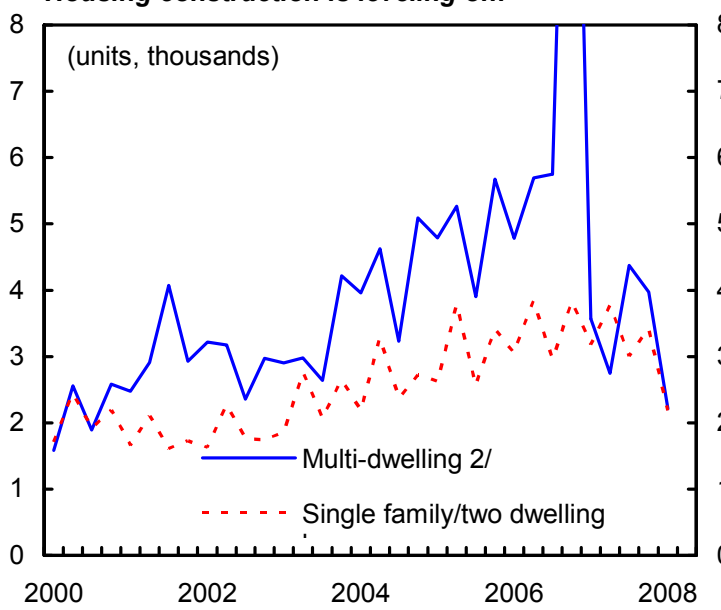

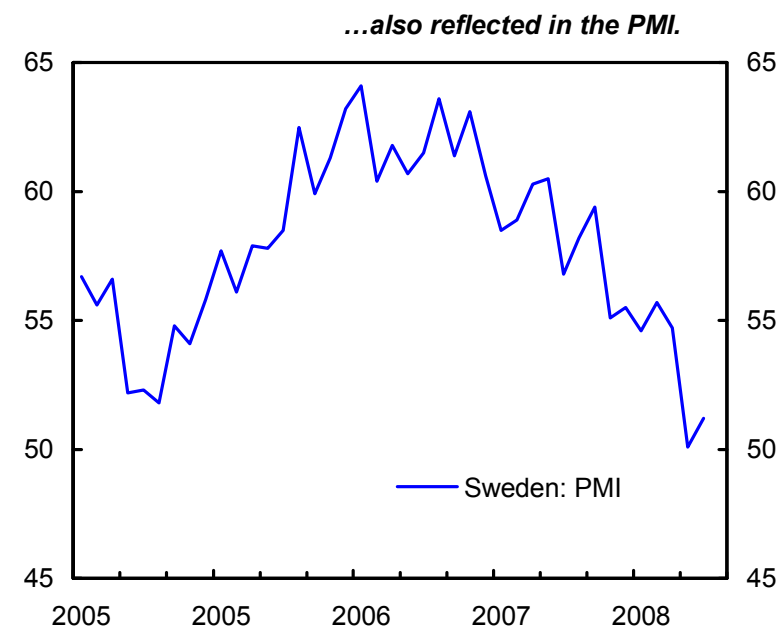

The NIER ${ }^{1 /}$ economic tendency indicator is also declining.

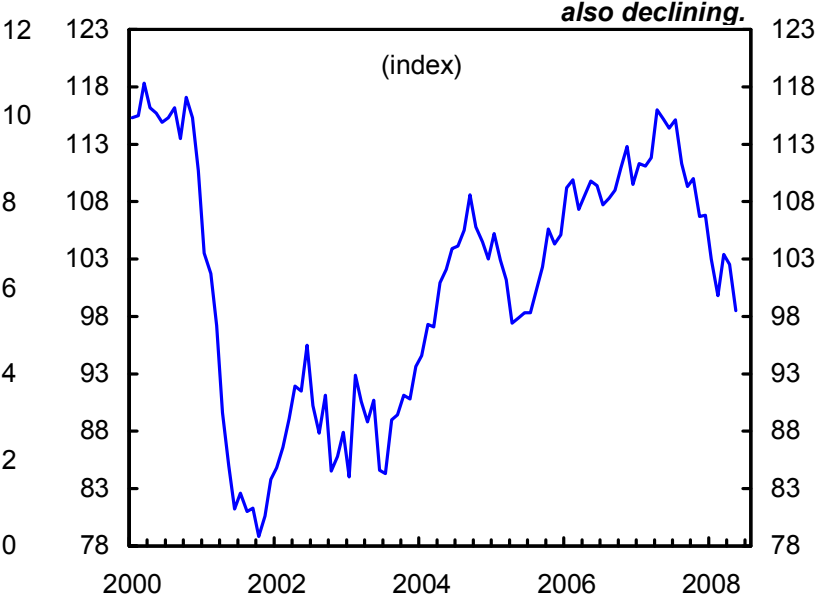

Car registrations dropped sharply recently.

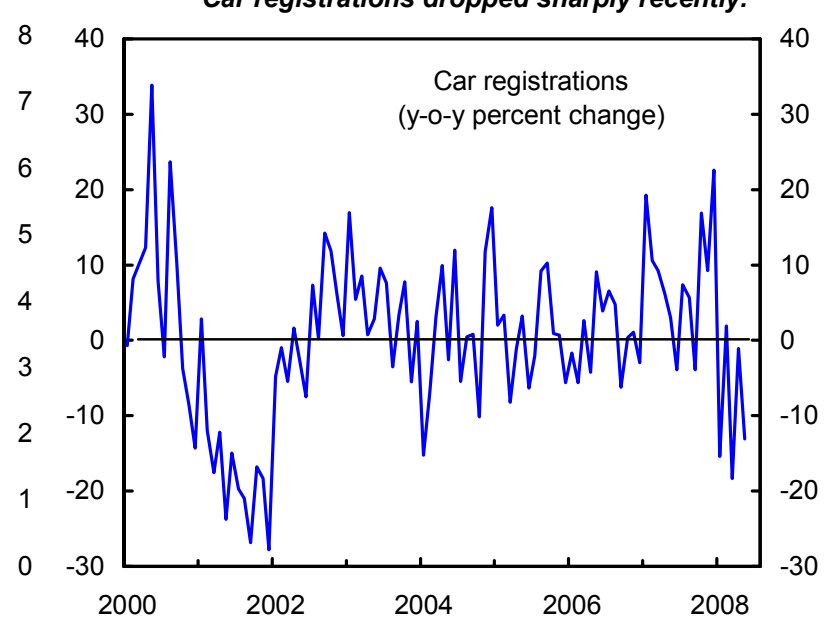

Source: IMF staff projections based on data provided by the authorities.

1/ National Institute of Economic Research synthetic indicator of economic ativity.

2/ Peak in late 2006 reflects law change (end of subsidy) effective 1/2007. 
Figure 2. Sweden--Quarterly National Accounts show that the Economy has been performing well

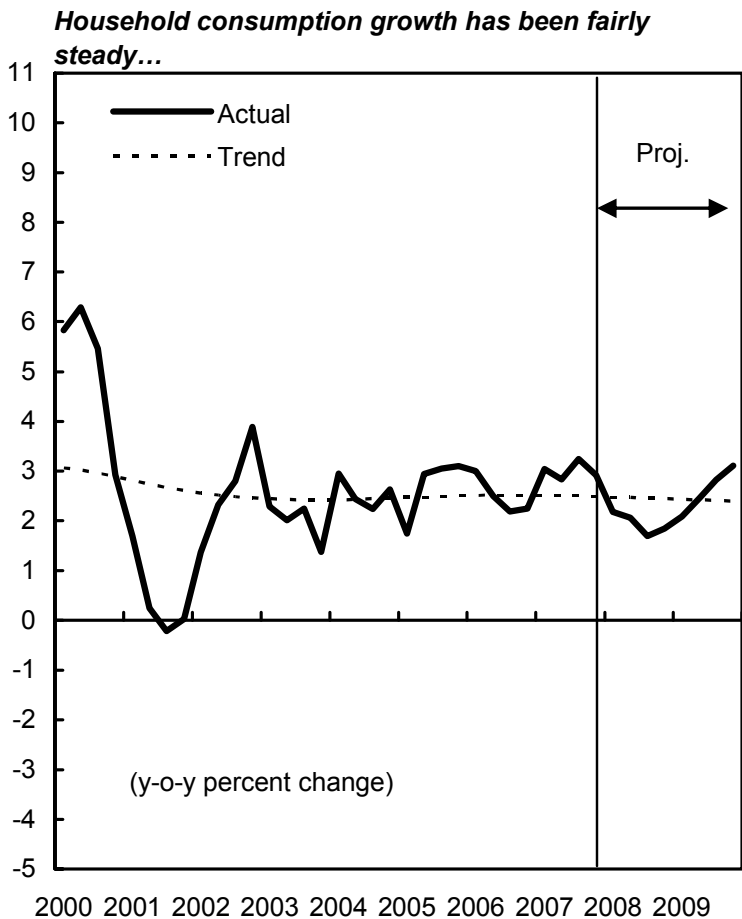

Trend export growth is between 5-7 percent...

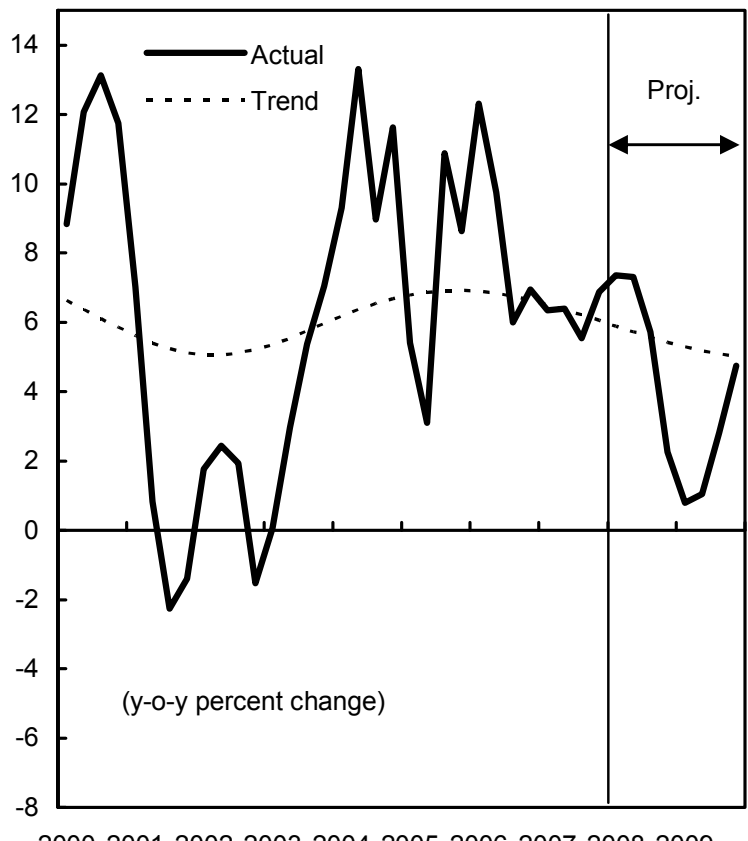

2000200120022003200420052006200720082009

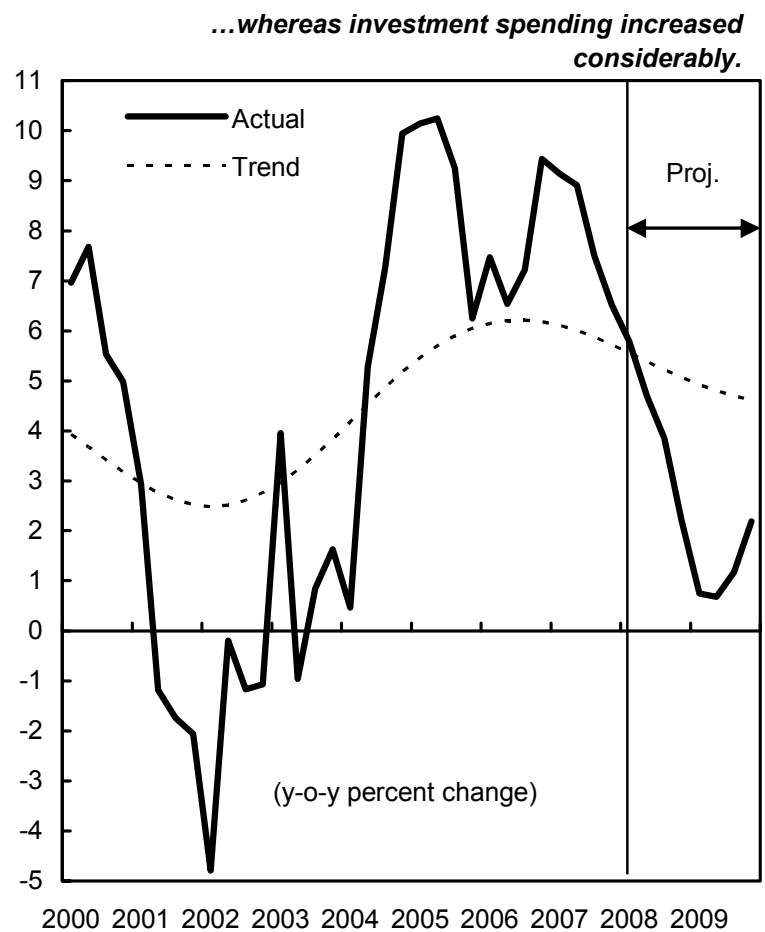

....Trend import growth has caught up.

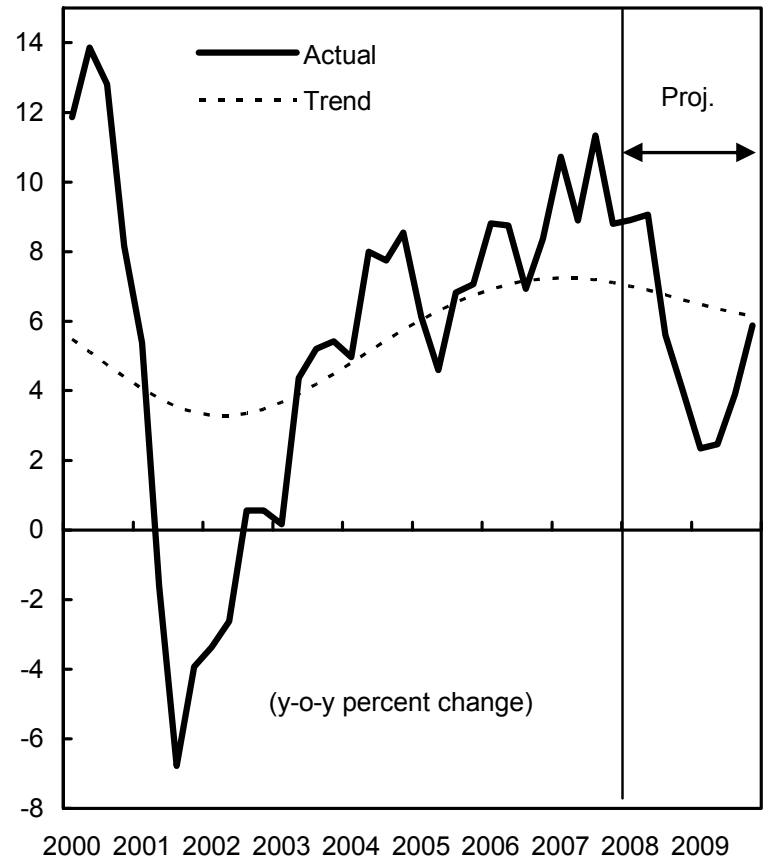

Source: IMF staff projections based on data provided by the authorities. 
Figure 3. Sweden--Labor Market Indicators have Improved in Recent Years
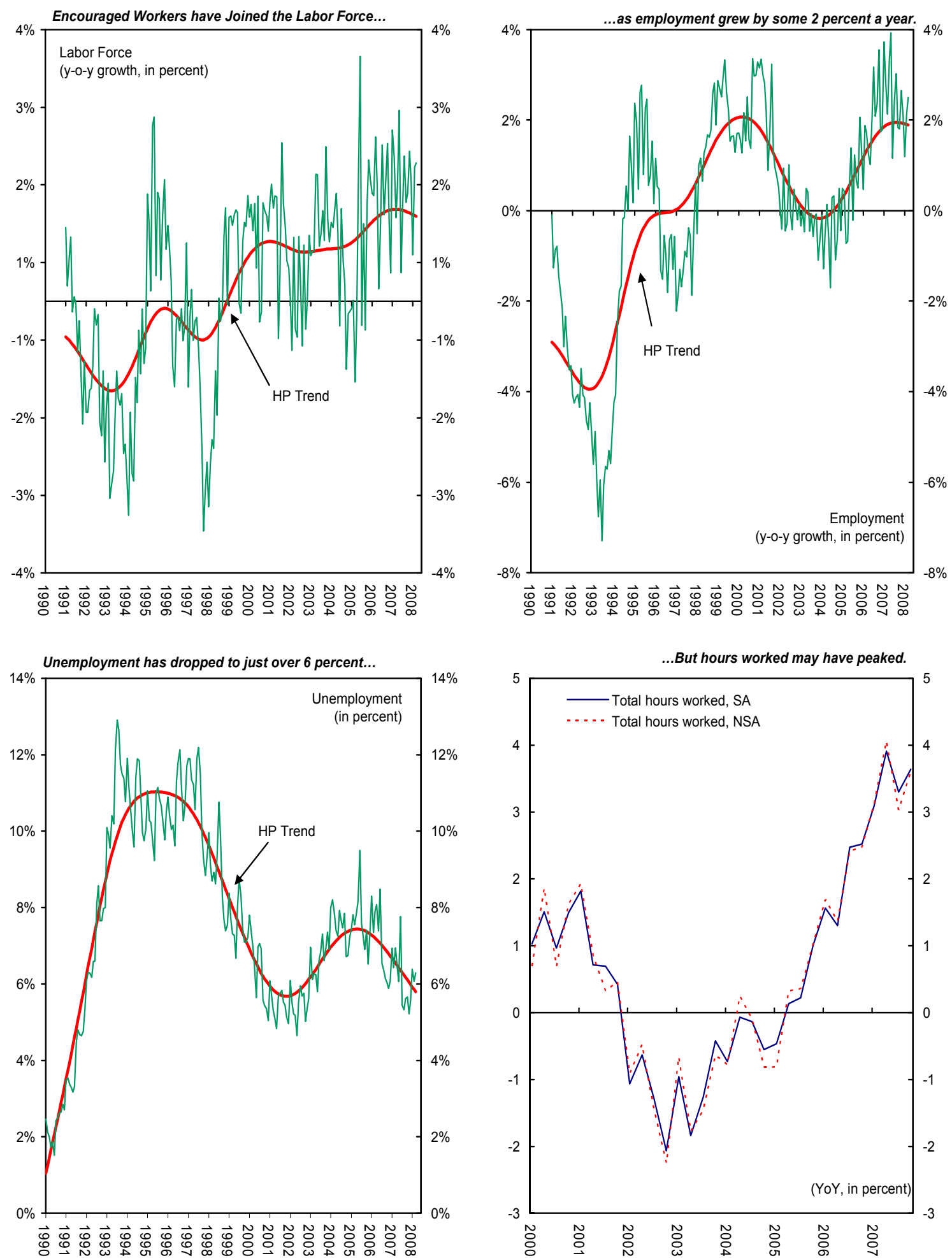
Figure 4. Sweden--Wages and Labor Costs are Rising
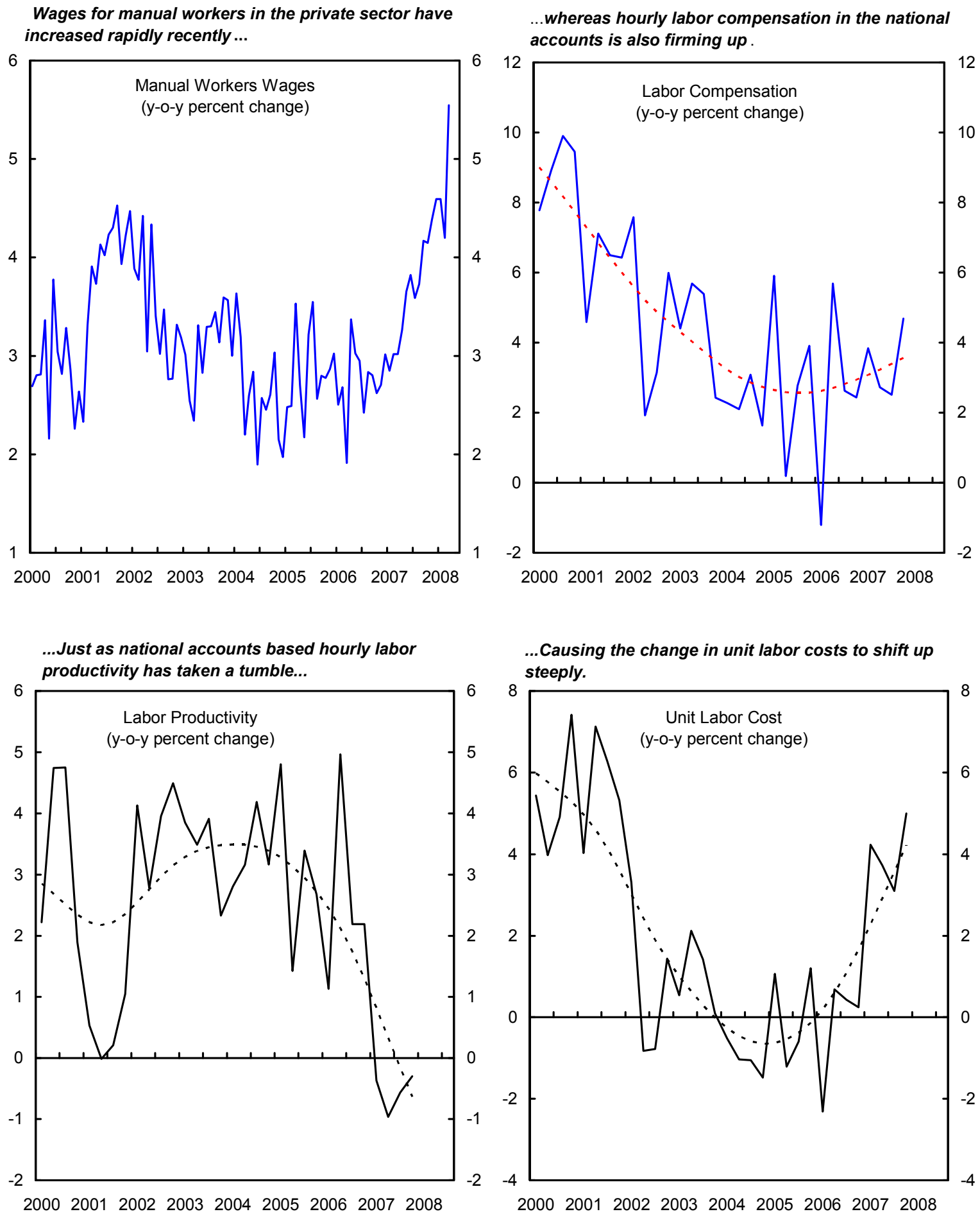

Source: Statistics Sweden 
9. Fiscal policy remained strong. Sweden continues its exemplary fiscal recovery since the crisis in the 1990s when the deficit reached 10 percent of GDP. The turnaround has been expenditure-led, but recent performance also experienced buoyant revenues. Debt is falling below 40 percent of GDP (Figure 5).

\section{With the strong fiscal adjustment and high private saving, the external current} account surplus reached 8 percent of GDP. Sweden's open economy is sensitive to global activity, which has been buoyant. The trade surplus is 7 percent of GDP. Growing net external assets and favorable returns contributed net factor payments of 2 percent of GDP. Foreign aid exceeds 1 percent of GDP (Figure 6).

\section{OUTLOOK}

11. Following global financial turbulence, the economy is projected to slow below potential in 2008 and begin to turn up in 2009. Consumer confidence has weakened, reducing retail spending. Business confidence has dropped less (Figure 7). The authorities and staff project growth of 2 percent in 2008 and 13/4 percent in 2009 (Table 2). Consensus growth forecasts are trending toward this outlook from above.

\begin{tabular}{|c|c|c|c|c|c|c|c|}
\hline \multicolumn{8}{|c|}{ Sweden: Medium-Term Outlook 1/ } \\
\hline & 2007 & 2008 & 2009 & 2010 & 2011 & 2012 & 2013 \\
\hline Real GDP & 2.7 & 2.0 & 1.7 & 2.8 & 3.0 & 2.8 & 2.5 \\
\hline Final domestic demand 2/ & 3.2 & 2.1 & 1.8 & 3.1 & 3.2 & 2.9 & 2.5 \\
\hline Consumption & 2.4 & 1.9 & 2.2 & 2.6 & 2.7 & 2.6 & 2.4 \\
\hline Fixed investment & 8.0 & 4.1 & 1.2 & 6.7 & 6.3 & 4.9 & 3.9 \\
\hline Net exports $2 /$ & -0.9 & 0.1 & -0.4 & -0.4 & -0.2 & -0.2 & -0.1 \\
\hline Exports & 6.0 & 5.8 & 2.4 & 4.3 & 5.0 & 4.8 & 4.5 \\
\hline Imports & 9.6 & 6.8 & 3.7 & 6.0 & 6.4 & 6.0 & 5.4 \\
\hline CPI inflation, pa & 1.7 & 3.4 & 2.8 & 2.0 & 2.0 & 2.0 & 2.0 \\
\hline Unemployment rate, pa & 6.1 & 6.6 & 7.1 & 6.9 & 6.4 & 6.2 & 6.0 \\
\hline Potential growth & 3.4 & 3.2 & 2.8 & 2.7 & 2.5 & 2.2 & 2.1 \\
\hline Output gap & 0.7 & -0.5 & -1.6 & -1.5 & -1.0 & -0.4 & 0.0 \\
\hline Current account balance & 8.4 & 7.5 & 6.8 & 6.3 & 6.1 & 6.0 & 6.0 \\
\hline $\begin{array}{l}\text { Source: Fund staff projection } \\
\text { 1/ Percent. } \\
\text { 2/ Contribution to growth. }\end{array}$ & & & & & & & \\
\hline
\end{tabular}

12. Sweden is well positioned to absorb some slowing. Softer growth has a silver lining in view of the high capacity utilization, consumer prices, and tight housing markets. At the same time, the strong fiscal position, the repo rate at $4 \frac{1}{4}$ percent, and the external current account surplus provide Sweden with policy room to respond. However, the banking system is showing growing risks, requiring close monitoring. 
Figure 5. Sweden--Fiscal Policies are Sound
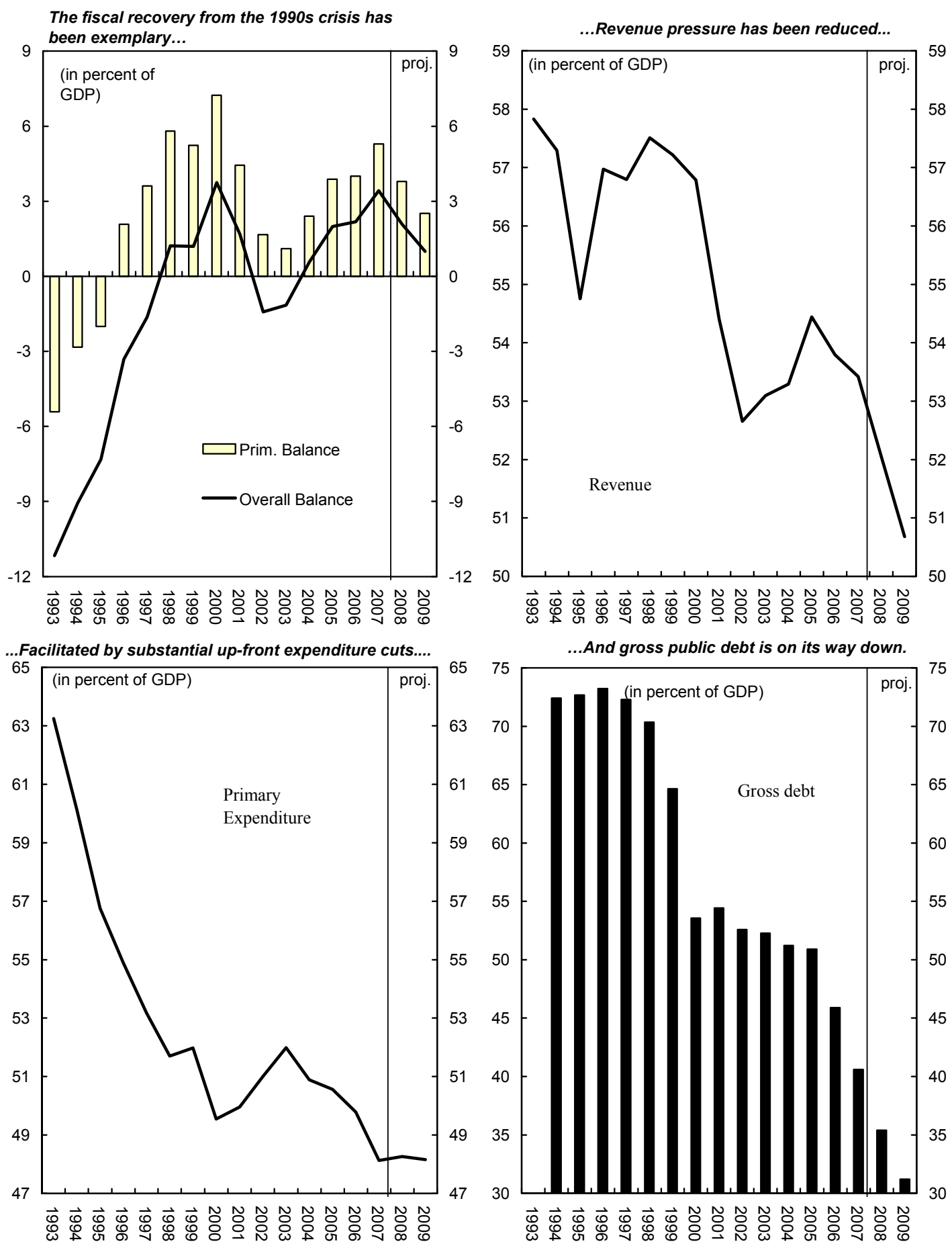
Figure 6. Sweden--Balance of Payments and International Investment Position Indicators
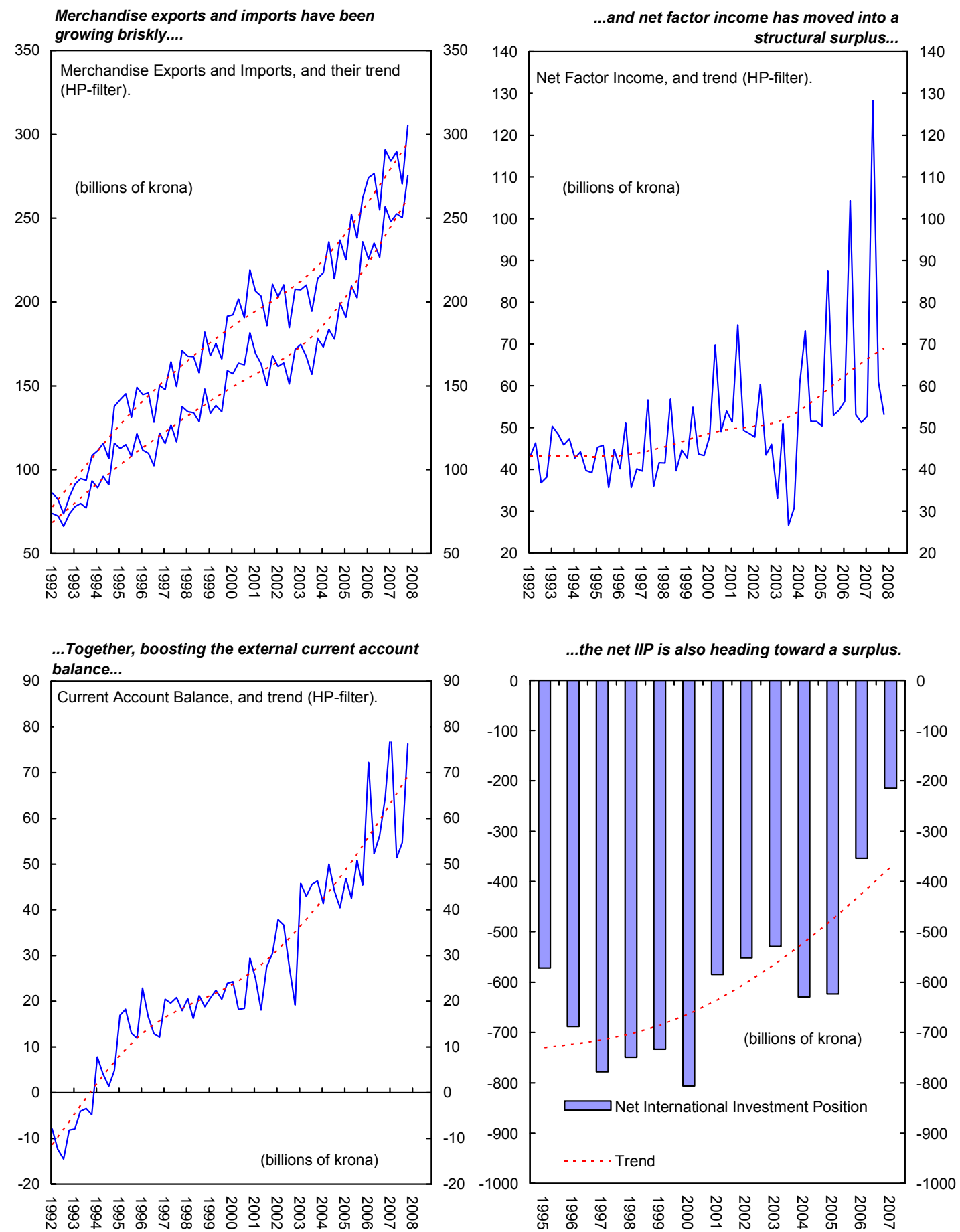
Figure 7. Sweden--Consumer and Business Confidence Indicators are Dropping

Consumer confidence has dropped since the global financial turmoil began...

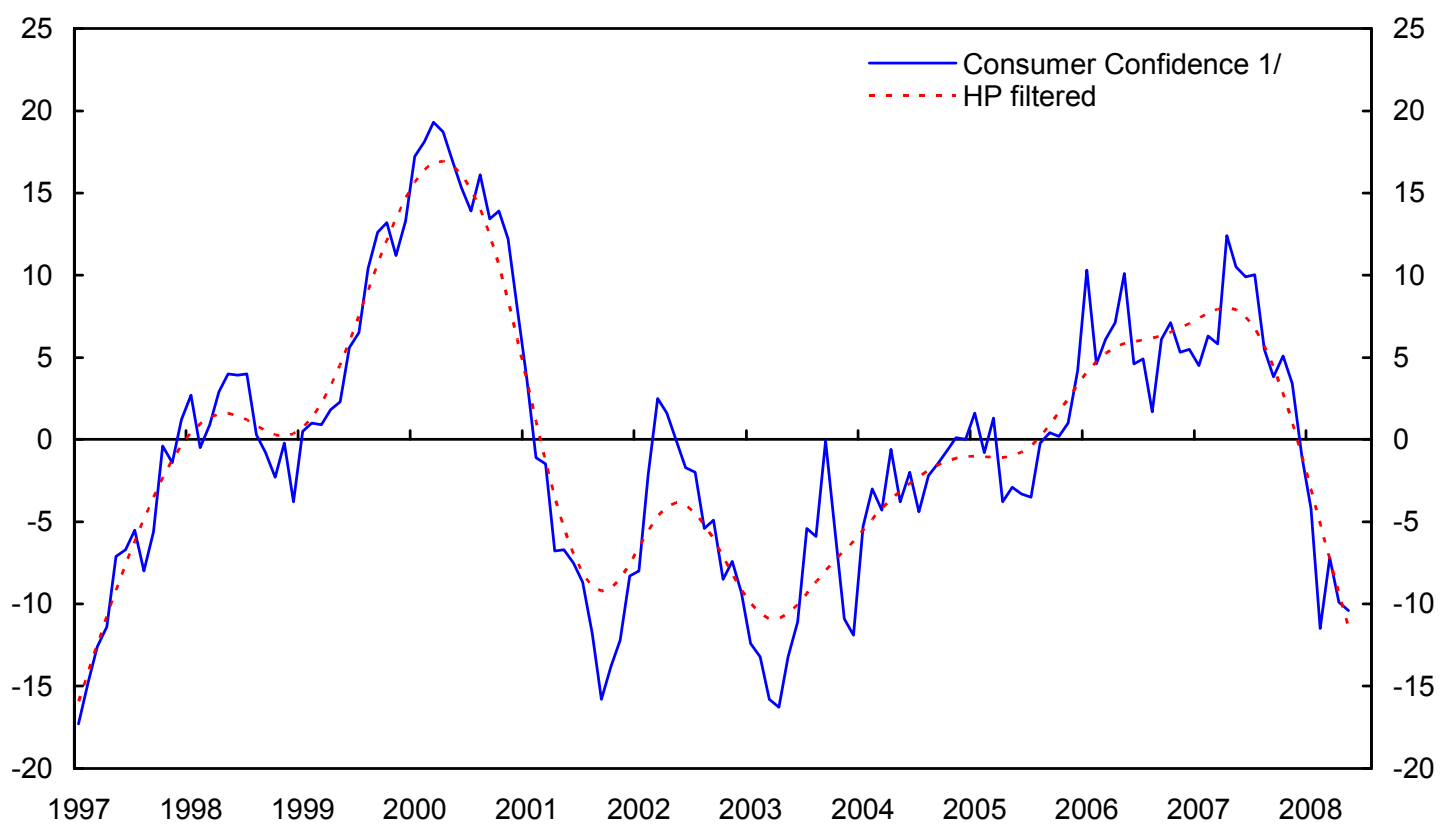

...business confidence has dropped less.

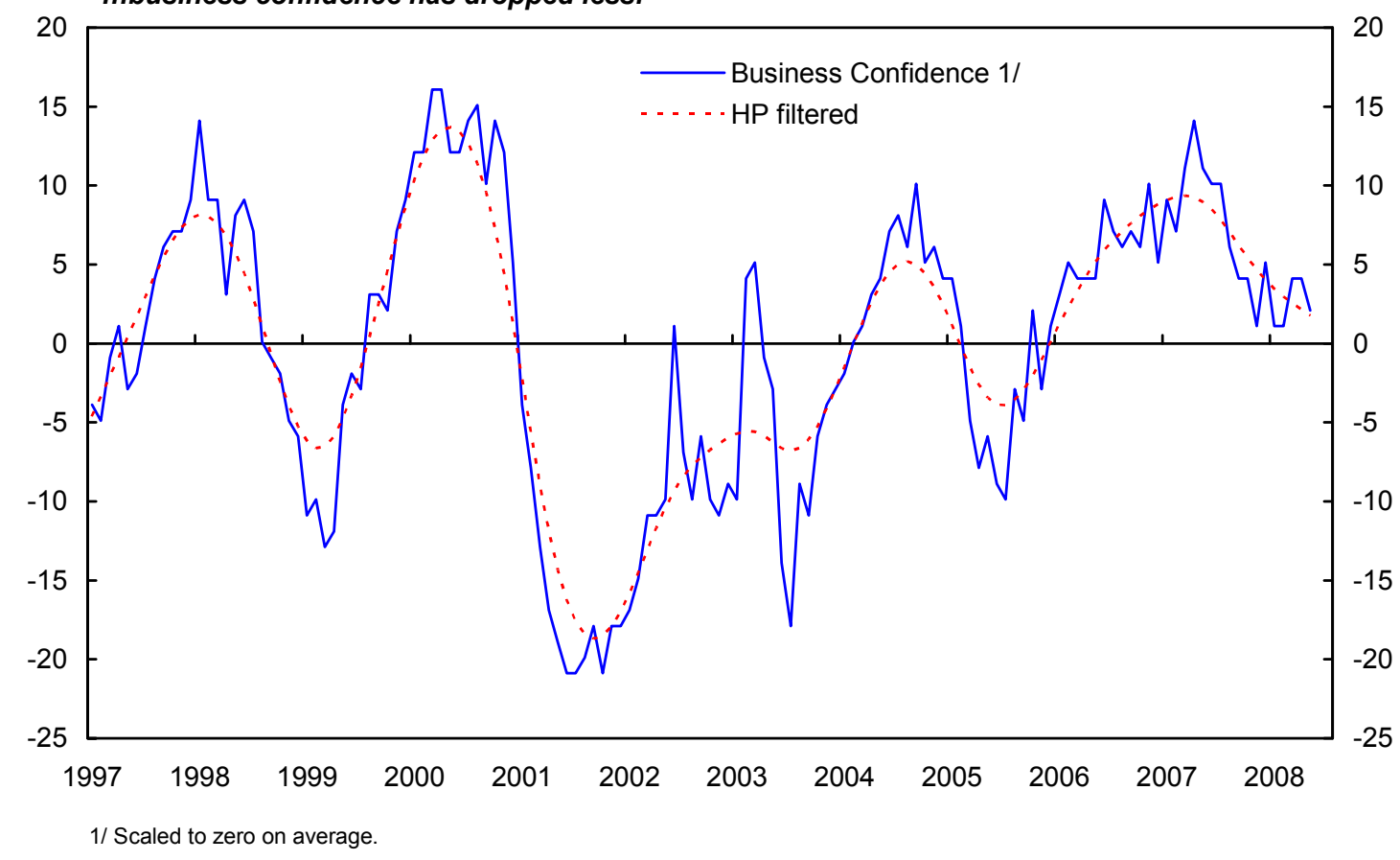




\section{Risks to growth for $\mathbf{2 0 0 8}$ are balanced; those for $\mathbf{2 0 0 9}$ depend on developments}

in the banks. If funding costs normalize and the Baltics achieve a soft landing, stable credit expansion should support growth. If turmoil persists, Swedish housing prices fall, and/or Baltic exposures sour, a credit crunch could slow growth below forecast.

14. Sweden's long-run outlook appears sound. Long-run potential growth likely ranges from $2-2 \frac{1}{4}$ percent. Sweden's population is projected to slow but not decline-the dependency ratio will rise (Figure 8). The working-age population is expected to slow with cohorts retiring. Further, TFP growth has been above average recently, which staff attributes to the structural recovery from the 1990s. It is assumed to level off at 1.1 percent a year going forward, akin to other high-income countries.

\begin{tabular}{|c|c|c|c|c|c|c|c|c|}
\hline \multicolumn{9}{|c|}{ Sweden: Long-Run Potential Real GDP 1/ } \\
\hline & \multicolumn{3}{|c|}{ Actual } & \multicolumn{5}{|c|}{ Projection } \\
\hline & $1970-79$ & $1980-89$ & $1990-99$ & $2000-09$ & $2010-19$ & $2020-29$ & $2030-39$ & $2040-50$ \\
\hline Real GDP & 2.4 & 2.3 & 1.7 & 3.1 & 2.2 & 2.0 & 2.0 & 2.1 \\
\hline TFP & 0.6 & 1.0 & 1.4 & 1.8 & 1.2 & 1.1 & 1.1 & 1.1 \\
\hline Hours Worked & -0.4 & 1.0 & -0.3 & 0.7 & 0.1 & 0.3 & 0.3 & 0.4 \\
\hline Working-age population & 0.1 & 0.3 & 0.4 & 0.6 & -0.1 & 0.1 & 0.1 & 0.2 \\
\hline Participation rate & 0.7 & 0.3 & -0.7 & 0.1 & 0.1 & 0.1 & 0.1 & 0.1 \\
\hline Employment rate & 0.0 & 0.1 & -0.4 & 0.2 & 0.0 & 0.0 & 0.0 & 0.0 \\
\hline Hours worked per employee & -1.3 & 0.2 & 0.6 & -0.2 & 0.1 & 0.1 & 0.1 & 0.1 \\
\hline Real capital stock & 3.0 & 2.4 & 1.9 & 2.2 & 2.6 & $\mathbf{2 . 0}$ & 1.9 & 2.0 \\
\hline \multicolumn{9}{|l|}{ Memorandum items: } \\
\hline Labor share of income & 65.5 & 65.5 & 62.4 & 63.2 & 63.4 & 63.3 & 63.3 & 63.3 \\
\hline Per-capita real GDP growth & 2.1 & 2.0 & 1.3 & 2.6 & 1.7 & 1.6 & 1.8 & 1.9 \\
\hline Labor productivity growth (per hour) & 2.4 & 1.3 & 2.0 & 2.5 & 2.1 & 1.7 & 1.7 & 1.7 \\
\hline
\end{tabular}

\section{Policy Discussions}

\section{With the economy in good shape, discussions focused on managing risks to}

banks and the real economy. Financial sector surveillance focused on bank risks, and how to strengthen Sweden's deficient remedial and resolution framework. Exchange rate surveillance focused on external and domestic stability as linked to the policy mix. Monetary policy risks have increased with inflation expectations drifting above the inflation target. Fiscal policy is strong, subject to monitoring contingent risks. 
Figure 8. Sweden--Demographic Indicators and Assumptions
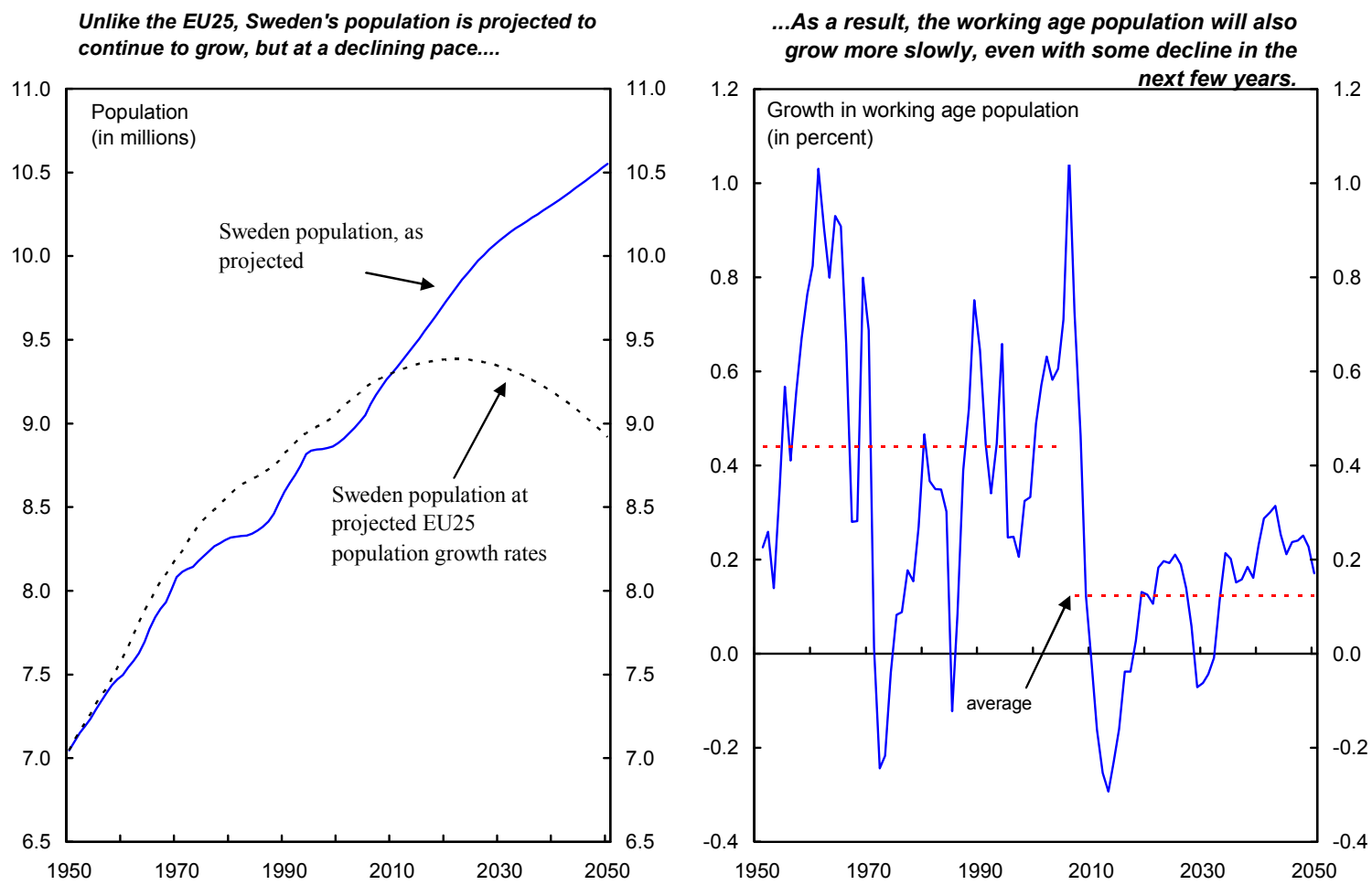

The dependency ratio has declined in recent years, but is projected to rise sharply looking forward.

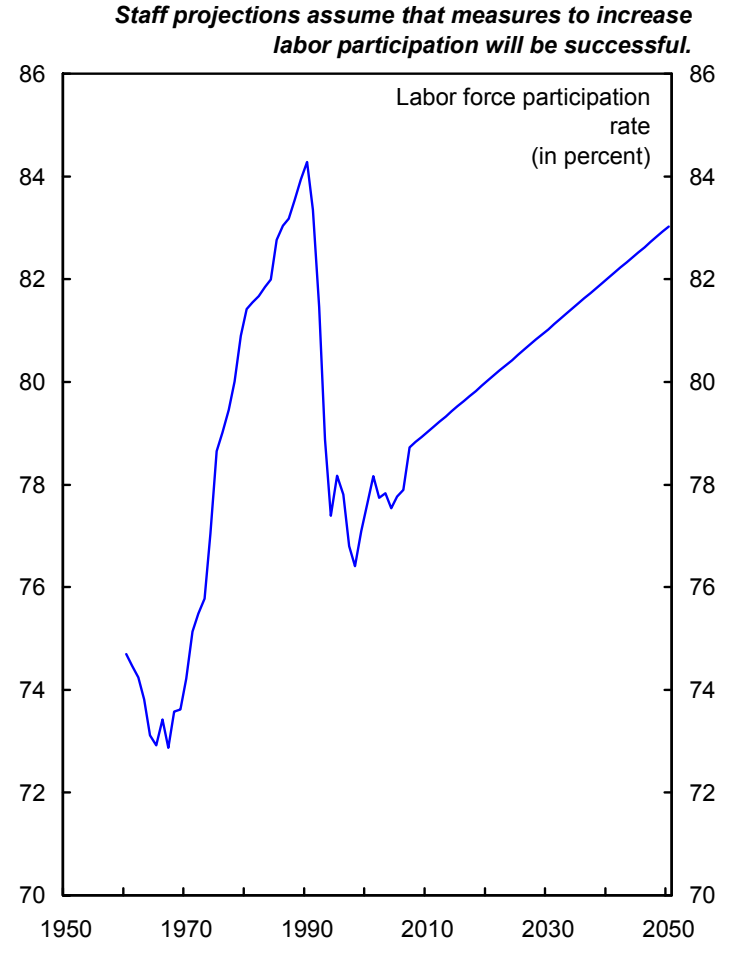




\section{A. Financial Sector Surveillance}

\section{Bank soundness}

16. Swedish banks have performed well so far (Tables 3-5). Four dominant banks (Nordea, SEB, Swedbank, and Handelsbanken) have significant cross-border exposures. They enjoyed record profits while expanding aggressively abroad. Return on equity increased as return on assets remained unchanged, signaling rising leverage. Tier 1 capital adequacy is 7 percent and overall risk-weighted CARs are 10 percent — adequate but not spectacular.

\begin{tabular}{|c|c|c|c|c|c|}
\hline \multicolumn{6}{|c|}{ Sweden: Selected Financial Soundness Indicators. 1/ 2/ } \\
\hline & 2003 & 2004 & 2005 & 2006 & 2007 \\
\hline Regulatory capital to risk-weighted assets & 10.5 & 10.6 & 10.5 & 10.5 & 10.2 \\
\hline Regulatory Tier 1 capital to risk-weighted assets & 8.0 & 8.3 & 7.7 & 7.8 & 7.5 \\
\hline Return on assets & 0.6 & 0.7 & 0.8 & 0.8 & 0.8 \\
\hline Return on equity & 12.5 & 15.9 & 18.1 & 19.9 & 18.5 \\
\hline Capital to assets (1/leverage) & 5.1 & 4.8 & 4.8 & 4.8 & 4.7 \\
\hline Nonperforming loans to total gross loans & 2.0 & 1.2 & 0.9 & 0.8 & 0.6 \\
\hline Net interest income to gross income & 64.4 & 58.9 & 52.4 & 49.2 & 52.4 \\
\hline Noninterest expenses to gross income & 63.5 & 59.4 & 56.4 & 55.2 & 55.7 \\
\hline Noninterest income to total income & 35.6 & 41.1 & 47.6 & 50.8 & 47.6 \\
\hline Noninterbank loans to noninterbank deposits & 142.6 & 130.8 & 137.4 & 135.7 & 139.8 \\
\hline $\begin{array}{l}\text { Source: Riksbank and Fund staff estimates. } \\
\text { 1/ End-period, in percent. } \\
1 \text { / Total banking system; for the four large banks }\end{array}$ & & & & & \\
\hline
\end{tabular}

\section{Sweden has little direct exposure to US subprime paper-instead exposure to the}

Baltics is significant. Swedbank and SEB are dominant players in the Baltics, with up to two-thirds lending market share (Figures $9 \& 10$ ). Each earns about a third of operating profits in the Baltics with 11 percent of their total lending there (in euros and local currency). Rising concerns over credit risks have led banks to cut loan growth. This is delicate, because too fast a retrenchment could undermine the profits and assets the banks are trying to protect. On the funding side (in euros, krona, and local currency), the global risk repricing has increased liquidity risk, as wholesale and securities-related borrowing represent an important source of the banks' total funding. Funding has tightened up and become more costly. Banks have responded in part by switching to covered mortgage bonds, which carry double collateral (of the underlying mortgages and the bank guarantee) and permit longer average maturities.

18. Market signals indicate heightened risks. Stock prices have dropped and credit default swap spreads have increased, notably for banks active in the Baltics (Figure 11). Staff discussed its background work on banks' default dependencies, using the latest nonlinear 
Figure 9. Sweden: Key Financial System Indicators

Four banks dominate the system...

In percent of total assets, end-2007

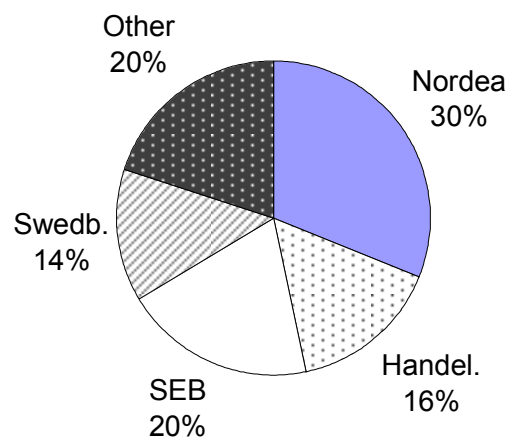

This exposure represents almost one third of total foreign bank funding ....

Key Home Countries for Baltics, end-Sept 2007

(in \% of total foreign bank funding to the Baltics)

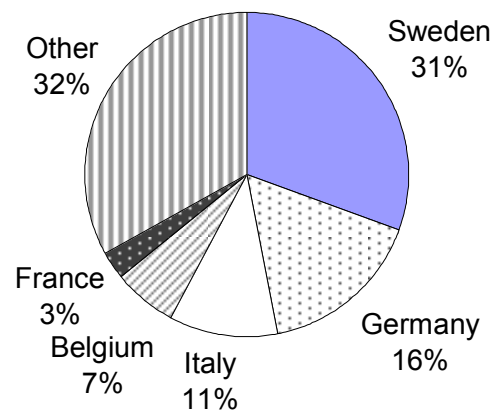

... two of which have signifcant exposure to the Baltic countries.

Direct exposure to Baltics

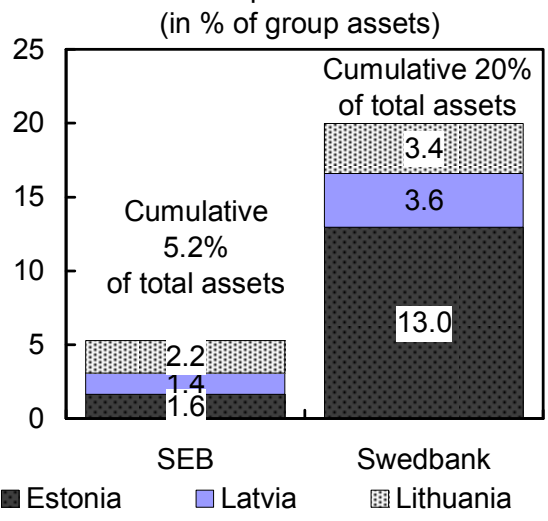

....and over 20 percent of total private sector credit in the Baltic countries.

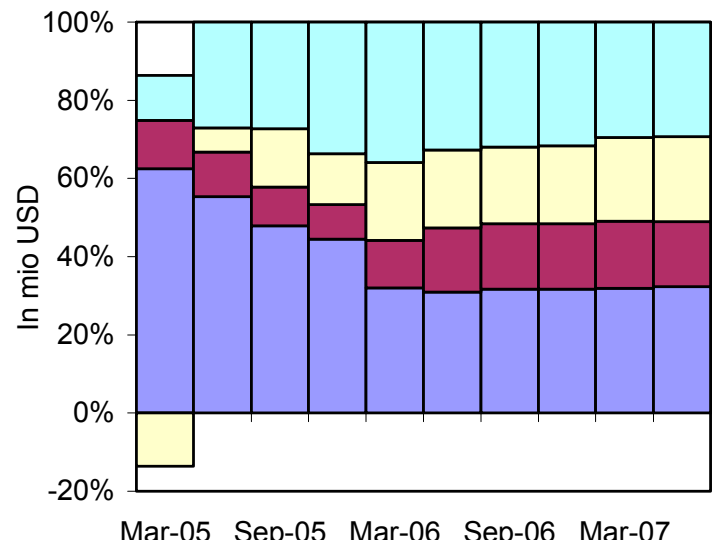

$\square$ Cross-border claims by foreign banks LLocal claims in foreign currency by foreign banks Local claims in local currency by foreign banks $\square$ Local claims by local banks 
Figure 10. Sweden: Key Financial Sector Indicators

Despite their recent rise, default probability of Swedish banks remains low compared to other large banks, ...

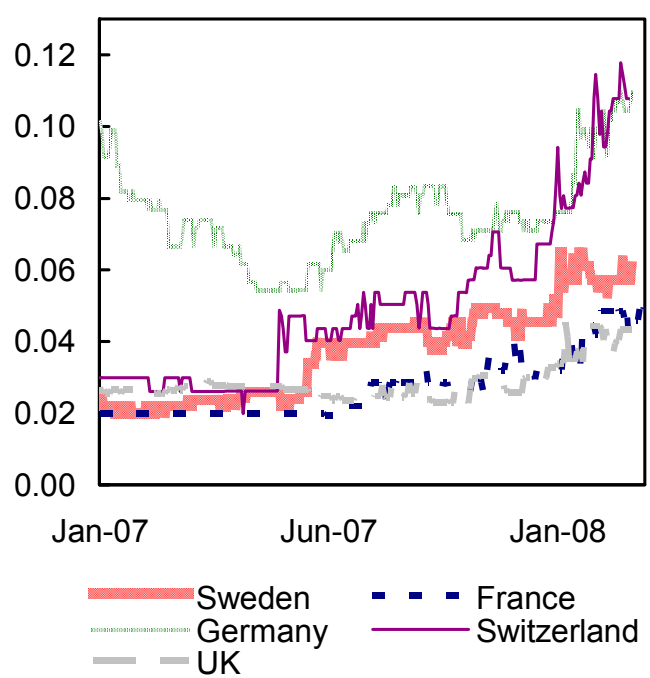

Funding costs have risen, in line with those in other mature markets.

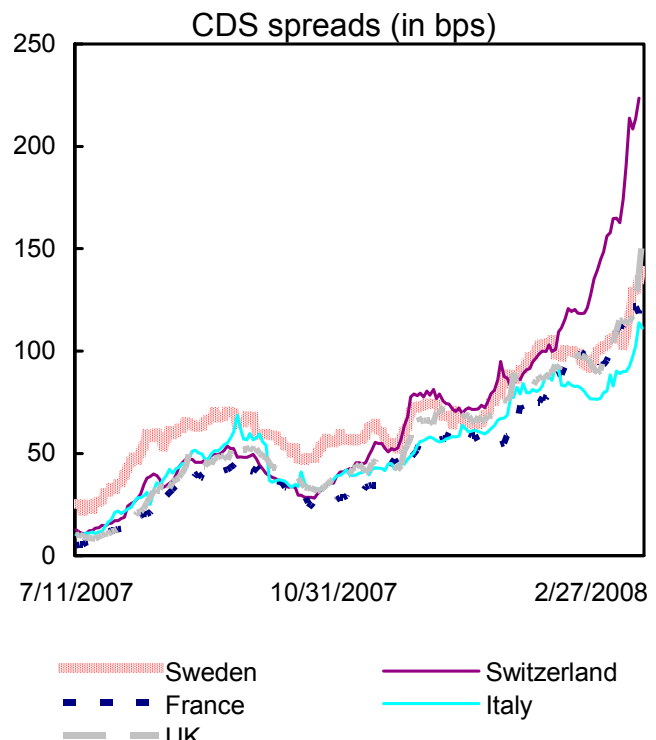

... partly supported by robust corporate sector performance.

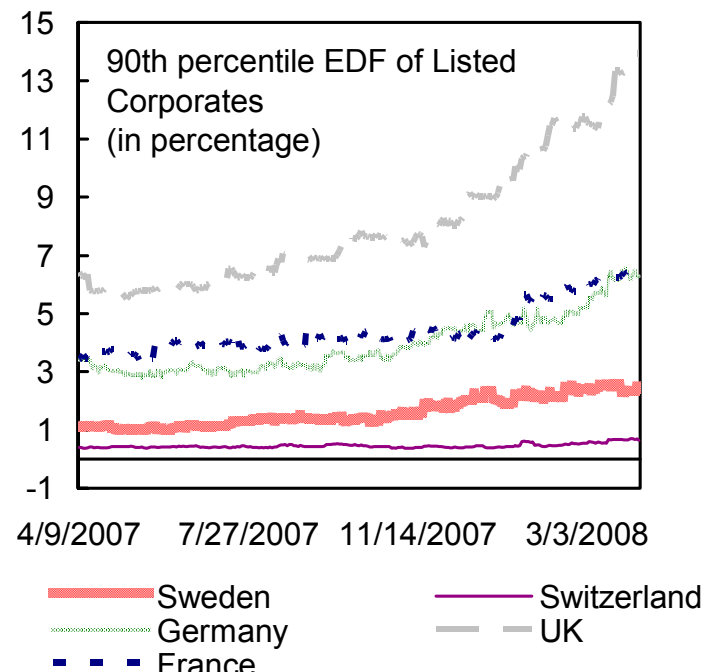

Despite deterioration, Swedish system remains sound, with 10 percent of banking assets at risk if banks with investment grade or lower credit rating default.

Swedish Banks: Assets in Distress Default Probability vs. \% Cumulative Assets

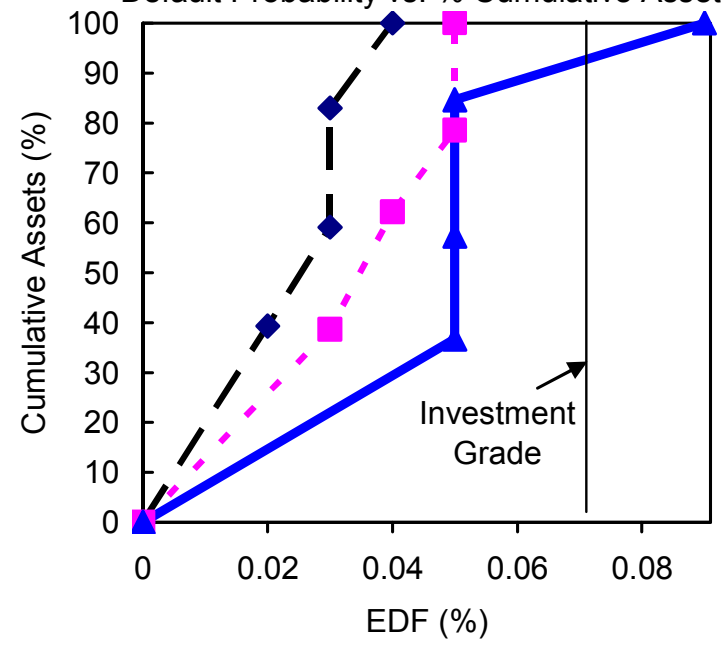

$\longrightarrow-39182-\square=39353 \longrightarrow 39547$ 
Figure 11. Sweden: Financial Market Indicators

Baltics exposure has hurt bank equities...

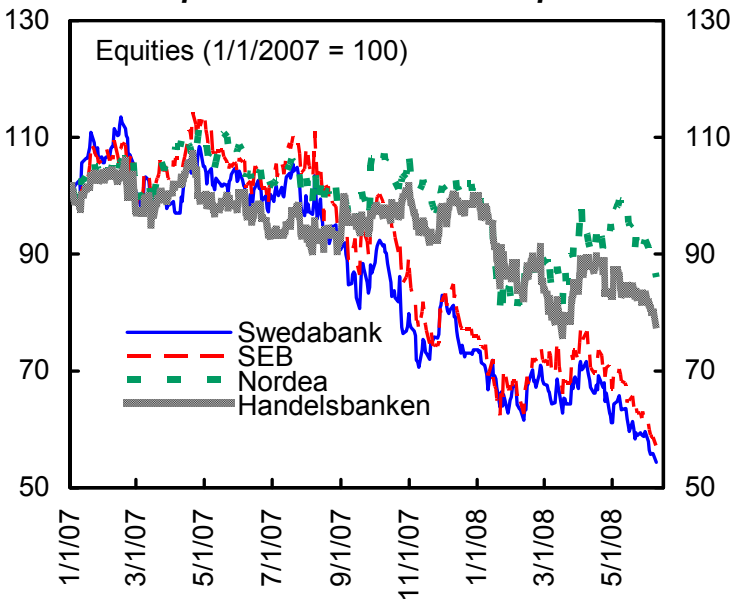

OMX and Euro stocks are highly correlated.

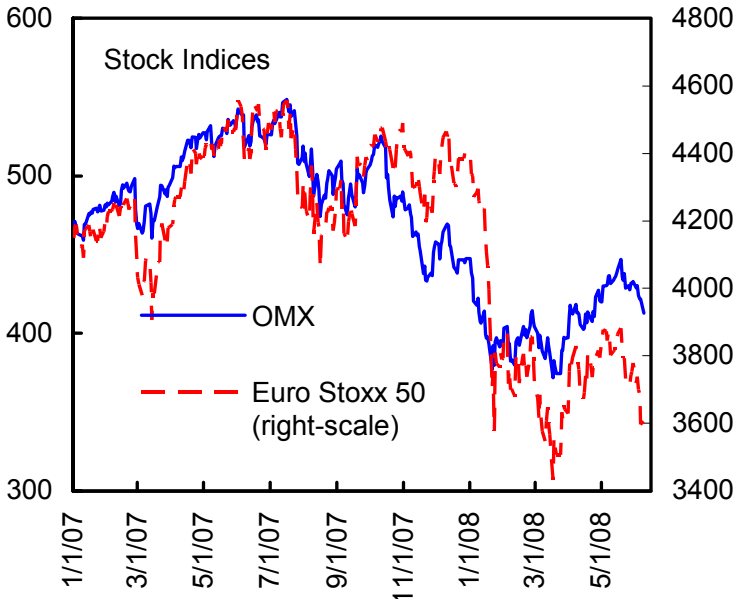

...And CDS spreads have increased.

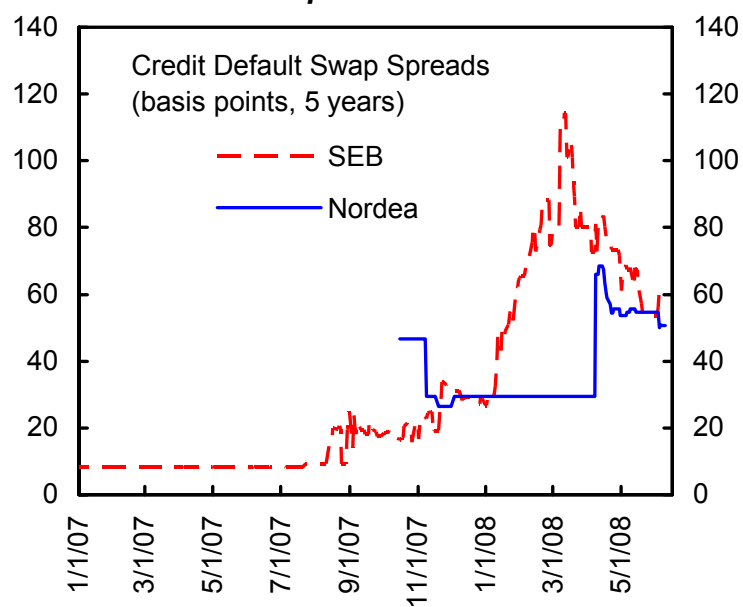

Interbank spreads have widened.

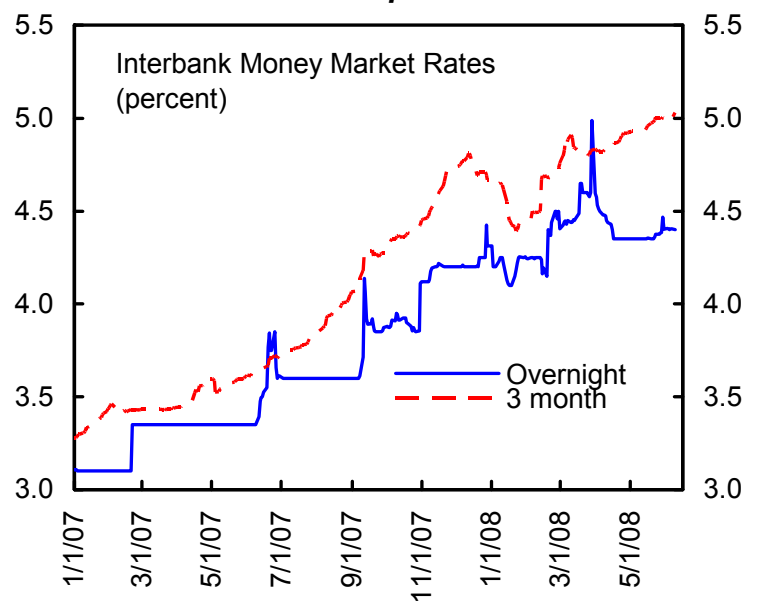

The yield curve has flattened...

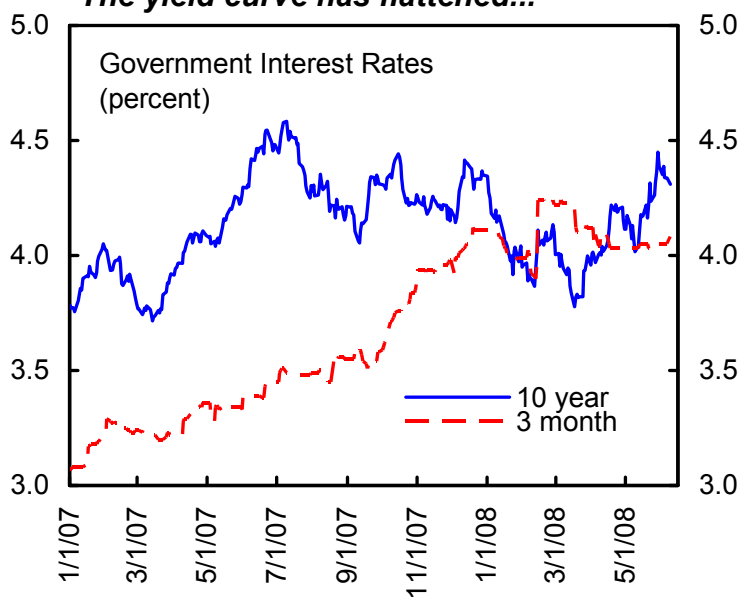

...As the krona is appreciating vs. the dollar.

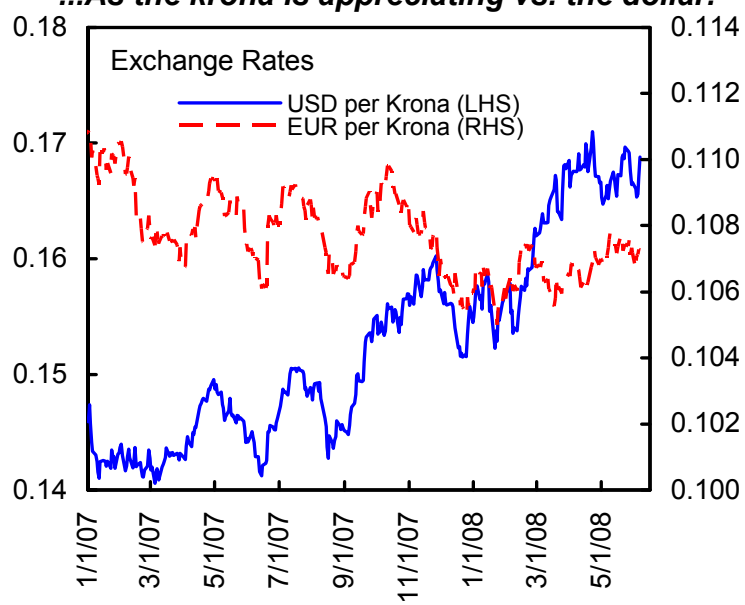

Source: Thomson Financial/DataStream and Bloomberg. 
techniques (Box 1). ${ }^{1}$ The Riksbank has drawn increased attention in its Financial Sector Stability Reports to the risks from the Baltics, as well as from the elevated Swedish house prices. The banks, in turn, signaled their enhanced focus on credit quality in the Baltics. Staff recommends that banks do not lower capital/asset ratios further (i.e. increase leverage), even though having moved to Basel II may allow them to do so, given their high share of mortgage lending that tends to have lower risk-weighting.

\section{Box 1. Default Dependencies and Bank Stability}

The soundness of one bank depends on overall system stability. As seen in a staff application for Sweden, the probability of default of one bank is linked to that of others, directly through interbank deposits and syndication, and indirectly through lending to common sectors and exposure to capital markets and proprietary trades. This default dependency can be nonlinear when the financial system experiences stress. Looking at bank risk individually and ignoring this interdependency overestimates financial sector resilience.

Staff analyzed the default dependency between the four Swedish banks with nonparametric models with the following results:

- $\quad$ The Swedish banking system remains stable but with a higher tail risk than six months ago. The joint probability of default (JPoD) or tail risk that all four banks default simultaneously has risen significantly, but less than the average probability of default (PoD) of individual banks. This indicates a buffer of resilience. For comparison, at the height of the global financial distress, the JPoD of 15 major international banks increased faster than their average PoDs, indicating that weaknesses in one or several institutions magnified risks for the entire system.

- $\quad$ Banks exposed to the Baltics have higher risk. Banks with high Baltics' exposure have seen their JPoD increase faster and their resilience depend increasingly on the soundness of the entire Swedish financial system. This calls for vigilance regarding their shock absorption capacity.

19. The authorities' and banks' own analyses suggest that the banks are prepared to cope with significant adverse events, should they come. For instance, the banks have sufficient buffers to cover loan losses up to 20 percent of total Baltic exposure while still meeting minimum CARs. Staff encouraged that stress-test assumptions also contemplate

\footnotetext{
${ }^{1}$ See A. Maechler: "Assessing Banking System Stability, An Application for Sweden" and "Exploring Financial Stability" (PPP) on the Sweden country website: http://wwwintranet.imf.org/departments/EUR/CountryInfo/Sweden/Pages/2008ArtIV.aspx
} 
"tail" risks that combine effects from concurrent shocks (e.g., long stagnation in the Baltics with maintenance of the currency pegs, or a recovery with valuation effects if a peg were to be adjusted). Baseline scenarios posit soft landings in the Baltics, but banks cannot ignore the possibility of tougher times. Indeed, spillovers from credit to liquidity risks would be problematic given the substantial reliance by banks on capital market funding and since a drying up of this funding could also cause a credit crunch in Sweden itself.

\section{Bank supervision and resolution}

20. Against this background, the Financial Supervisory Authority (FSA) is working to enhance cross-border supervisory cooperation with Scandinavian and Baltic partners. The FSA is moving toward replicating the supervisory colleges among Scandinavian countries in the Baltics. Banks and the FSA are also proceeding with the implementation of Basel II. Eight banks have permission to use internal risk-based models. Staff sees room to use Pillar II and stress testing to bolster capital adequacy, even in the absence of a coordinated effort at the European level. The FSA needs adequate resources to address high staff turnover, and assess the quality of banks' balance sheets with more on-site inspections of credit policies and portfolios, and less reliance on auditors' reports.

\section{Staff's core recommendations centered on beefing up Sweden's bank remedial} and resolution framework. The 1990s crisis was addressed with facilities that are no longer in place. It would be risky to rely on a similar approach if new bank stress were to hit because the banks are much larger today, operate cross-border, and rely more on capital markets. Bank resolution in Sweden falls under regular corporate law, which is too slow for prompt remedial action and to meet the special needs of the payments system. ${ }^{2}$ The responsibilities between the FSA, Riksbank, Deposit Insurance Agency, and fiscal authorities are not clear, which could lead to costly problems.

\section{The Ministry of Finance is drafting a new bank resolution framework. Staff discussed key features:}

- $\quad$ The FSA needs the authority and tools to implement strict prudential measures in a coherent, comprehensive, step-by-step, graduated framework. It should range from provisions for special consultations for early stress assessment, to firmer measures in a remedial context, all the way to decisive bank resolution measures.

- $\quad$ It needs to be based on written code that defers to specialized courts to ensure timeliness of judicial oversight, while preventing appeals from blocking the implementation of supervisory decisions.

\footnotetext{
${ }^{2}$ In 2006, a small bank experienced stress but could not be intervened. After nine months of court proceedings, the owners finally entered the bank into bankruptcy to limit their own liability.
} 
- It would need to include all banks, as special treatment for systemic banks accentuates moral hazard and adds legal complexity.

- Immediately after a bank license is revoked, authorities should take effective control, replace management, and trigger the deposit guarantee. The authorities should have a wide range of tools to wind up a failing institution, from the partial sale of its assets to arranging its acquisition or merger with another bank.

- $\quad$ To minimize moral hazard, the owners of a failing bank should take the first hit. To minimize the cost to the Treasury, authorities should have the legal option to facilitate a merger into a stronger institution, or redeem shares of a failing institution at a price corresponding to its value in the absence of state aid, subject to administrative procedures.

- Legislation needs to prescribe a clear and credible priority of claims on bank assets, with potential losses for some creditors to discourage excessive risk taking.

23. The authorities were in broad agreement, but were investigating several details. They noted that the legislation would need to remain under corporate law, but agreed that specialized courts should be established for quick resolution. They were considering to invoke the new framework only for systemic banks. And they were assessing the legal possibilities for resolving a failing bank without contravening European law. An FSAP update could further elaborate on these and other financial sector issues. ${ }^{3}$

\section{B. Exchange Rate Surveillance}

24. The Swedish krona is freely floating as determined by market forces. At constant REER, the external surplus would remain high, and the IIP turn positive, bolstering net factor earnings. However, the REER should increase in future as fiscal tightening ends and policy interest rates are higher on average than in the past - supporting the krona and reducing over time the large current account surplus (Tables 6-7). The velocity of this adjustment is difficult to predict because it also depends on the behavior of trading partners.

\section{CGER analysis suggests that the krona is 10-15 percent below its expected} medium-term value (Box 2). ${ }^{4}$ CPI and ULC REERs suggest similar conclusions (Figure 12).

\footnotetext{
${ }^{3}$ Sweden's FSAP was in 2002 (IMF Country Report, No. 02/161).

${ }^{4}$ See A. Brunner: "Exchange Rate Surveillance" (PPP) on the Sweden country website: http://wwwintranet.imf.org/departments/EUR/CountryInfo/Sweden/Pages/2008ArtIV.aspx
} 
Figure 12. Sweden: Real Effective Exchange Rate Developments
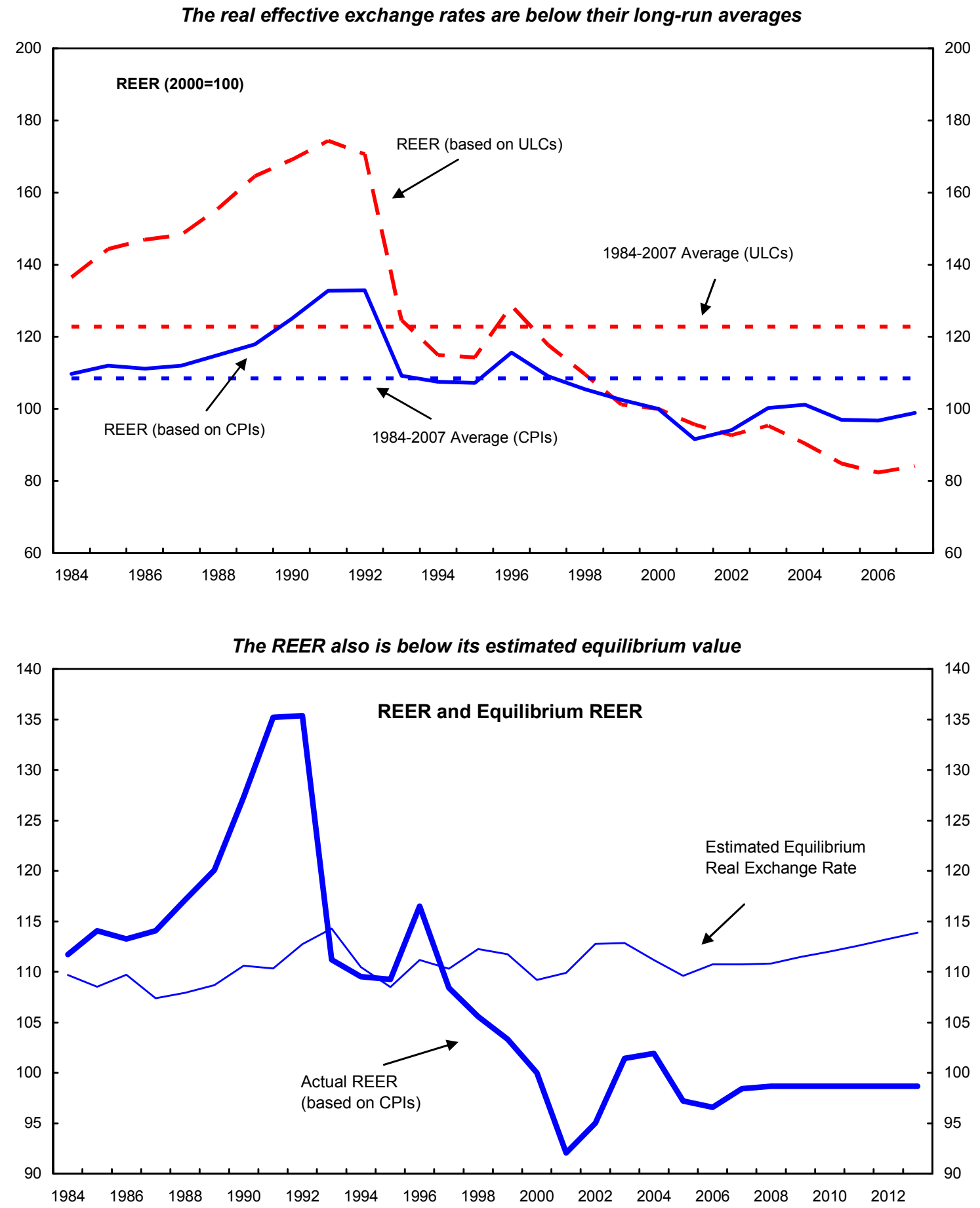

Source: WEO database, and IMF staff caclulations. 


\section{Box 2. CGER Estimates}

The macroeconomic balance approach reflects domestic absorption and saving-investment balances. It estimates a Swedish (norm) current account surplus of 3.2 percent of GDP. Two important variables are the current account and fiscal surpluses. These factors are offset somewhat by the growing dependency ratio, which reduces saving. Using Sweden-specific elasticities, the REER would need to appreciate 12 percent to lower the surplus to the norm.

The equilibrium real exchange rate approach models the exchange rate on fundamentals, including the stock of net foreign assets (NFA), return characteristics, etc.. By this metric, the REER appears 16 percent below its estimated medium-term equilibrium value.

The external sustainability approach asks what the REER would have to be to stabilize the NFA position going forward-finding 23 percent undervaluation. (This indicator is mechanical and less informative - analysts comment that at its stage of demographics, Sweden could be expected to have a positive IIP, instead of the actual negative one.)

26. The authorities and staff considered the soft krona in the context of the fiscalmonetary policy mix. Sweden turned its fiscal balance from a large deficit to a surplus, boosting saving and the current account, while cutting inflation. Monetary policy is an inflation targeting regime - the dampened inflation induced the Riksbank to maintain low policy rates for some time, relaxing the krona. The interaction of tight fiscal policy and loose monetary policy contributed to softening the exchange rate and boosting the external balance. However, the extended period of low interest rates eventually contributed to higher domestic asset prices, rising wage demands, and a rebound in inflation. Thus, fiscal and monetary policies should now recalibrate to continue securing domestic and external balance.

27. This analysis has implications for future policy mix. Fiscal policy has room to support domestic demand in a slowdown. Monetary policy should be tight to lean against the wind of imported inflation and unwind elevated inflation expectations. While the authorities need to guard against risks of excessive fiscal accommodation, as domestic demand finds support and interest rates stay firm, the krona should strengthen and the external surplus ease.

\section{Monetary Policy}

28. The Riksbank is an inflation targeter. The target is 2 percent CPI inflation with a margin of \pm 1 ppt (Figure 13). The Riksbank publishes policy committee minutes with attribution of individual members, and a three-year inflation forecast and corresponding policy interest rate path. Sweden is one of the most transparent inflation targeters.

29. Staff discussed whether the Riksbank had been late in normalizing rates. During 2003-07, the Bank kept policy rates below a CPI Taylor rule or inflation targeting rule (Figure 14). The economy gathered pace, as did asset prices, including housing (Figure 15). 
Figure 13. Sweden--Inflation Forecast and Expectations
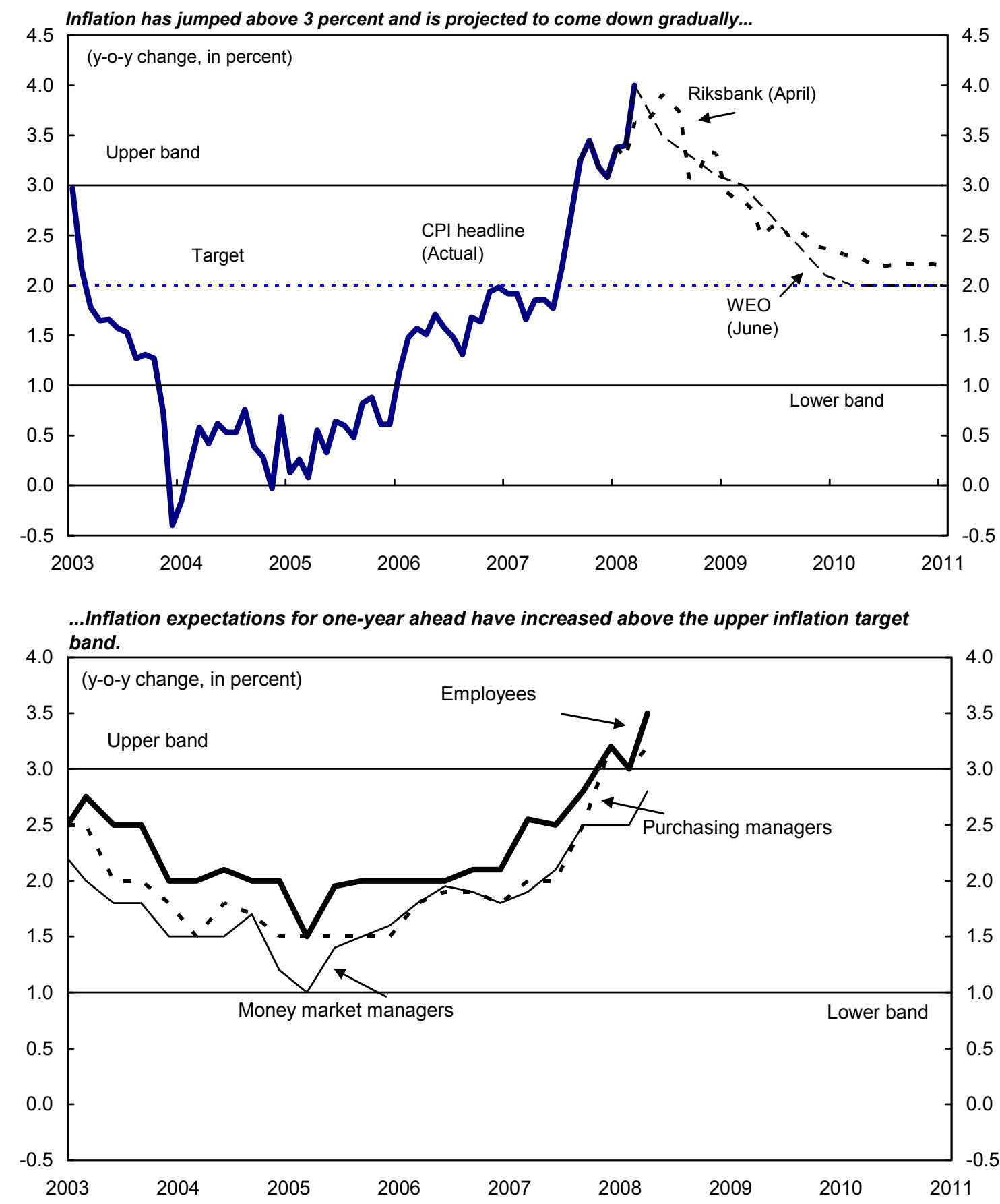

Source: Statistics Sweden; Prospera Research; and Fund staff calculations. 
Figure 14. Sweden--Monetary Policy Indicators

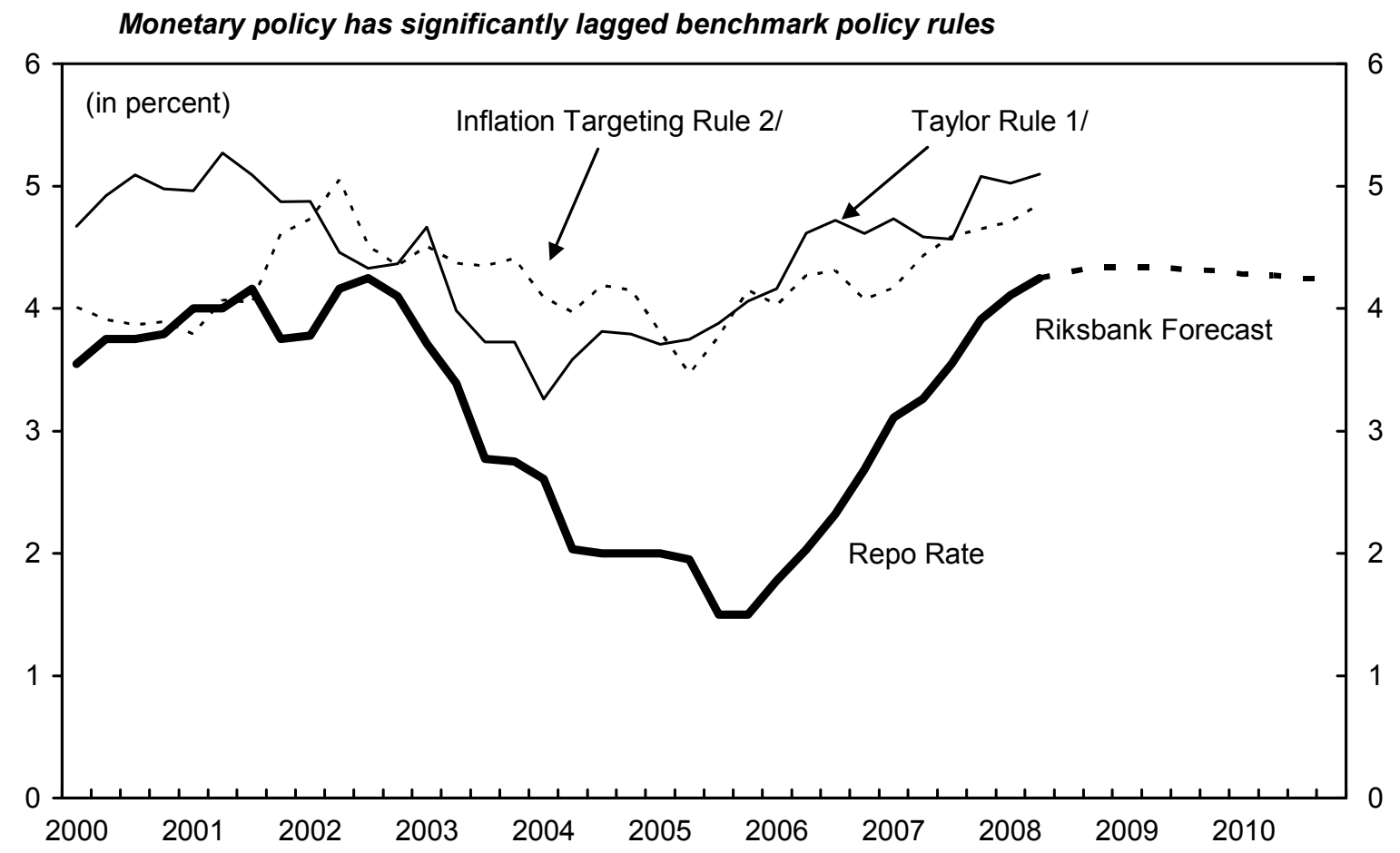

$1 /$ Taylor Rule $=4 \frac{1}{4}+1 / 2$ output gap $+1 / 2$ inflation gap; inflation target $=2$ percent

$2 /$ Inflation Targeting Rule $=41 / 4+2 *$ inflation expectations gap; expectations by money market managers.

The Riksbank also was accommodating later than the ECB or the Fed.

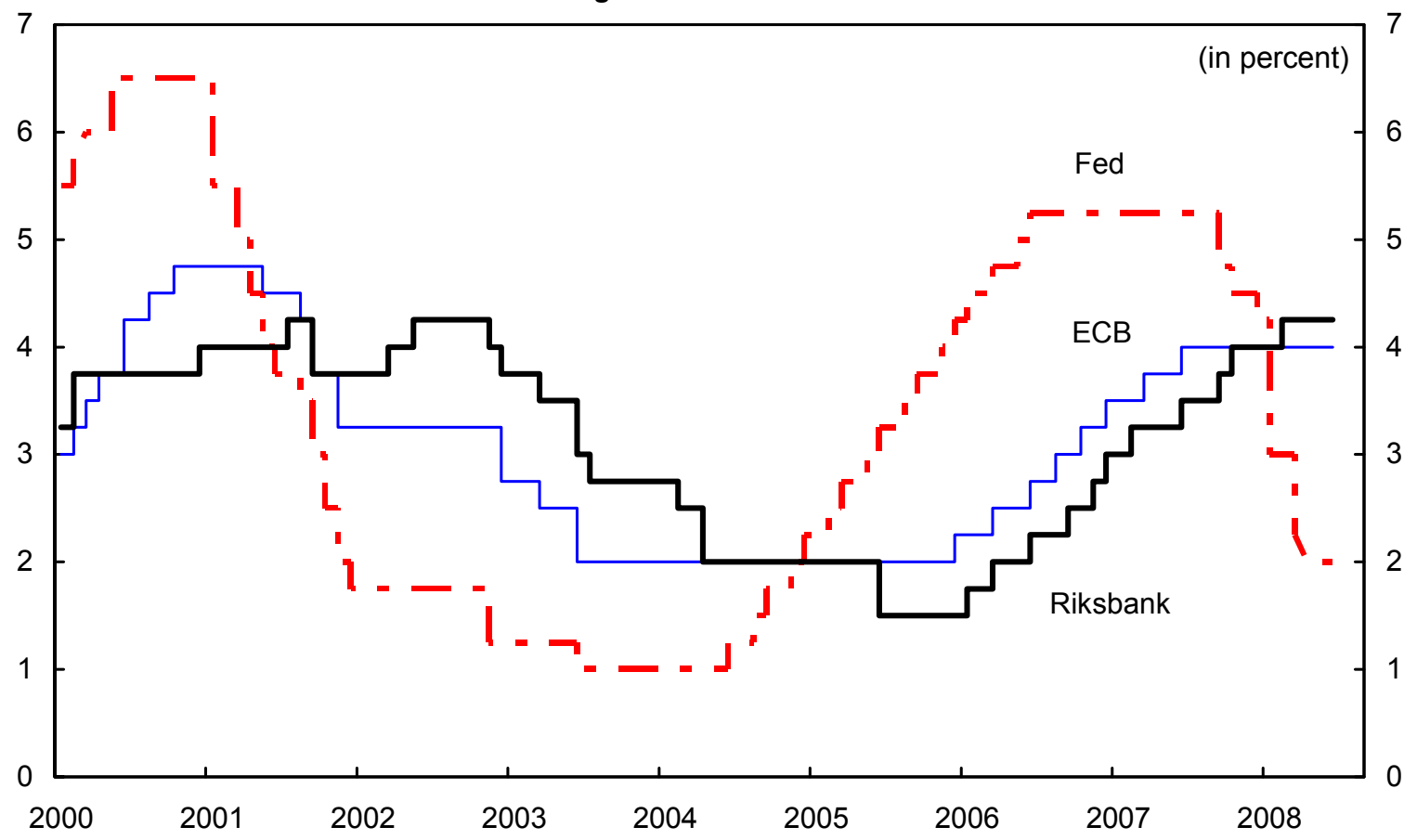


Figure 15. Sweden--Price and Credit Developments

Core inflation has increased...

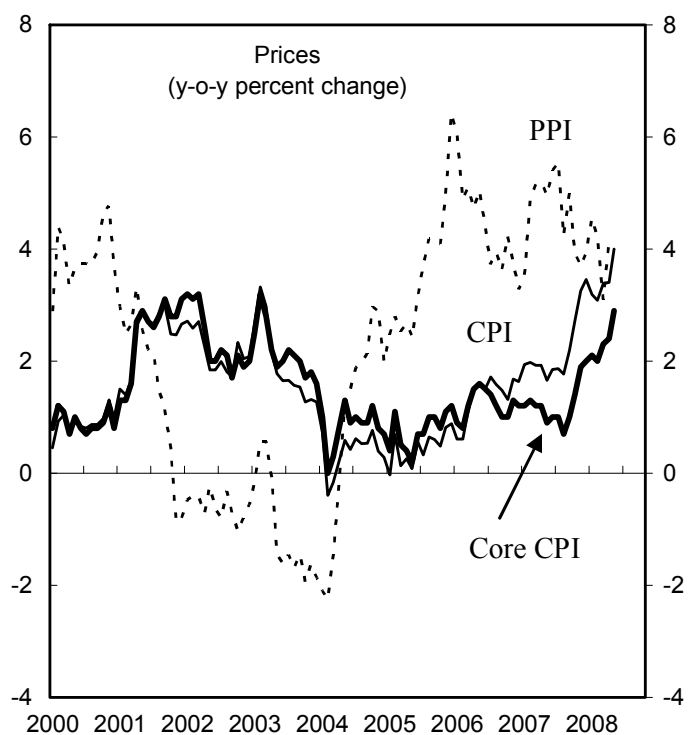

House prices also pushed up...

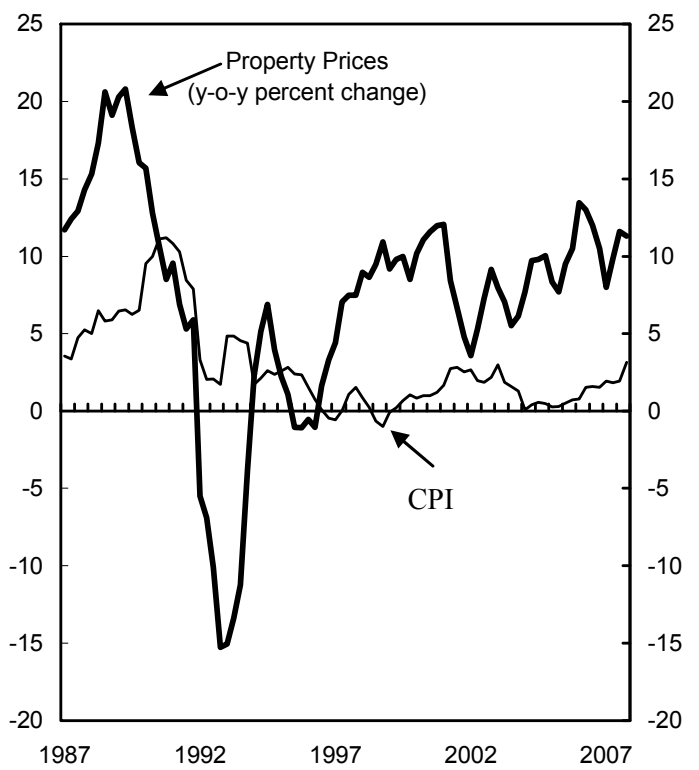

....as credit growth has accelerated

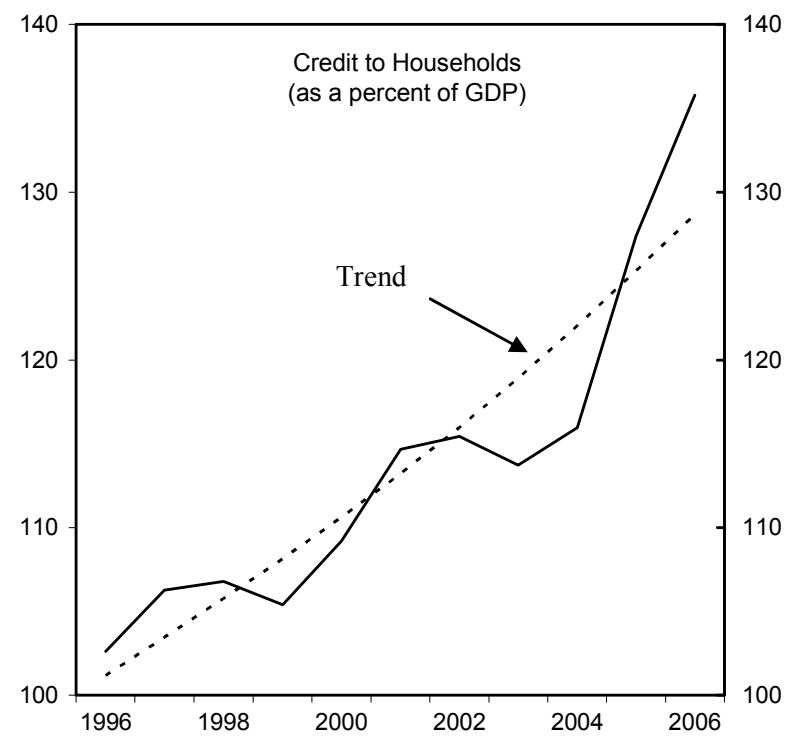

...leading to possible overvaluation relative to fundamentals

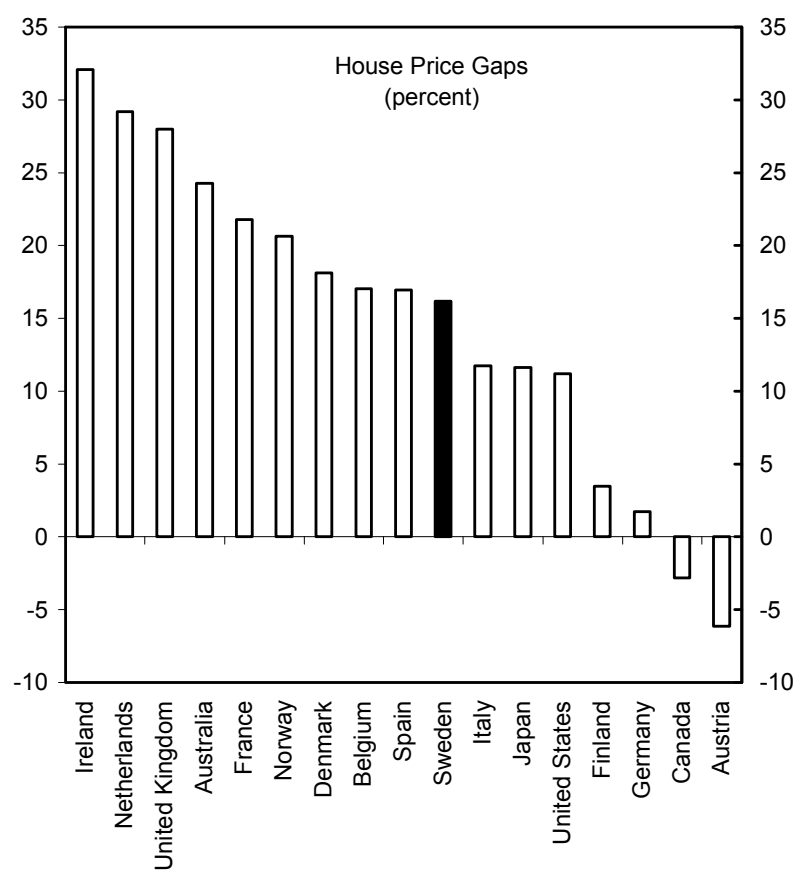

Source: Statistics Sweden, Riksbank, WEO (2008), and IMF staff calculations. 
Then, as the favorable international backdrop abated and with higher resource utilization, inflation rose, core inflation ticked up, and wage settlements and inflation expectations increased. The repo rate reached 41/4 percent in February 2008-late in the cycle. The Riksbank stressed its steady rate increases since 2006, and that this was on target of policy rules using the CPIX, which excludes interest rates to prevent perverse policy feedbacks. However, since the mission, inflation has increased further and the CPIX has been downgraded as underpredicting on trend headline inflation. The authorities now use several indicators to gauge pressure.

30. There was agreement that policy success means anchoring inflation expectations. Inflation expectations are drifting up above the 2-percent target. The neutral policy rate is around $4 \frac{1}{4}$ percent, and actual rates should oscillate around that level. Since current inflation pressures should not be allowed to slip into second round effects, the staff therefore recommended that the repo rate should have an upward bias, weighing elevated inflation indicators against some relief that should come with the economic slowdown. The authorities did not disagree with staff.

\section{Fiscal Policy}

31. Fiscal policy is subject to two rules: (i) an average surplus of 1 percent of GDP over the cycle, and (ii) an expenditure ceiling for central government and social security outlays. Local governments have little independent financing. This framework endeavors to address Sweden's demographic transition and commitments under the welfare state; and originated in reaction to the scary deficits in the early-1990s. The framework is very valuable, but its implementation requires cyclical dating and is not fully anchored in a long-run analysis.

\section{The 2008 Fiscal Policy Bill aims the surplus at 2.9 percent of GDP, with further} strengthening through 2011 on current policies. Its centerpiece is a SEK11 billion expansion in the earned income tax deduction. Together with other measures, tax cuts are 0.6 percent of GDP. These are offset by lower disability and other entitlement outlays - so that the structural surplus is little changed in 2008. On current policies, including these reforms and subindexing of some allocations, the authorities project a fiscal surplus of 4 percent of GDP by 2011.

\section{Given this strong fiscal position and slowing growth, the authorities are expected} to offer fiscal support in the 2009 budget (Table 8). They are expected to cut income taxes further and increase spending on infrastructure, R\&D, and preschooling. Staff believes the stimulus should not exceed 1 percent of GDP. Such support would not undermine Sweden's strong fiscal stance, and would be prudent in view of contingencies worth noting: 
- The supply reforms ${ }^{5}$ (see below) include entitlement cuts, which could lead to some substitution between programs or displacement of beneficiaries from the central to lower levels of government. The net fiscal savings are therefore difficult to estimate.

- $\quad$ The earned income deduction is a variant of the earned-income tax credit, which in some countries has proven costly. Also, support for household services has met with great demand and could also turn out costly.

- $\quad$ The sizeable surplus could trigger rent seeking and unproductive spending.

- The slowdown, coupled with bank risks, could reduce revenue and lead to contingent fiscal needs.

34. The authorities explained their fiscal measures to boost labor supply (Box 3).

These include scaling back active labor market programs and tightening sickness and unemployment insurance schemes. Further, in 2007, Sweden introduced a job and development guarantee for young and long-term unemployed and immigrants. Some taxes and social contributions were cut to boost participation.

- $\quad$ The earned income deduction has removed important distortions in the marginal tax schedule. Some of this benefit may be offset by income effects that vary along the income distribution. Interlocutors explained that this involved careful compromises in view of the unusual hump-shaped income dependent standard deduction - a feature unique to Sweden.

- $\quad$ The targeted incentive programs have so far provided ample net savings for the central government. However, over time, here too, there may be some netting out as agents adapt their behavior or as some displacement occurs to other programs and levels of government. If the economy stays strong, this effect should be limited.

35. The interaction of the fiscal policy measures got some attention. The measures are courageous and well taken in Sweden's extensive welfare state. However, it is recognized that the combination of targeted and broad-based measures can lead to complicated tax and benefit system interactions that subtract from transparency. Going forward, it would be important therefore not to multiply narrowly targeted programs - to benefit transparency and reduce compliance costs. The authorities and other stakeholders actively monitor and evaluate the labor supply and demand measures to track their impact on employment, hours worked, and at different levels of government budgets, which is welcome.

\footnotetext{
5 See A. Jousten: "Labor Market and Taxation" (PPP) on the Sweden country website: http://wwwintranet.imf.org/departments/EUR/CountryInfo/Sweden/Pages/2008ArtIV.aspx
} 


\begin{tabular}{|c|c|c|}
\hline \multicolumn{3}{|c|}{ Box 3. Fiscal Steps to Boost Labor Supply } \\
\hline Year & Income tax & Social programs \\
\hline \multirow[t]{4}{*}{2007} & $\begin{array}{l}\text { New earned income deduction that is more } \\
\text { generous for people aged } 65+\text { : The } \\
\text { interaction of the deduction with the } \\
\text { income-dependent personal allowance } d e \\
\text { facto generates a reduced flat tax for } \\
\text { incomes above SEK 110,000. }\end{array}$ & $\begin{array}{l}\text { Reduction of nonpension social contributions for } \\
\text { people aged } 65+\text { (born after 1937). }\end{array}$ \\
\hline & $\begin{array}{l}\text { Income tax credit on purchase of } \\
\text { household services. }\end{array}$ & $\begin{array}{l}\text { Introduction of New Start jobs in the commercial } \\
\text { sector with elimination of employer social } \\
\text { contributions for long-term unemployed, sick, } \\
\text { and disabled, for periods up to the duration of } \\
\text { out-of-job status (max. } 5 \text { years; preferential rules } \\
\text { for young; double subsidy period for } 55+\text { ) }\end{array}$ \\
\hline & & $\begin{array}{l}\text { Reduction of nonpension employer social } \\
\text { contributions for people aged } 18-25 \text { by one half. }\end{array}$ \\
\hline & & $\begin{array}{l}\text { Introduction of Step-In jobs for immigrants with } \\
\text { employer wage subsidies. }\end{array}$ \\
\hline \multirow[t]{3}{*}{2008} & $\begin{array}{l}\text { Earned income deduction made more } \\
\text { generous. }\end{array}$ & $\begin{array}{l}\text { Elimination of nonpension contributions for all } \\
65+.\end{array}$ \\
\hline & & $\begin{array}{l}\text { Expansion of new start jobs to all sectors and } \\
\text { introduction of well again jobs with even } \\
\text { stronger incentives for previously sick. }\end{array}$ \\
\hline & & $\begin{array}{l}\text { Harmonization of unemployment insurance } \\
\text { contributions across funds. }\end{array}$ \\
\hline
\end{tabular}

\section{The Staff explored the possibility of a public sector balance sheet serving as a} long-run fiscal anchor. Indeed, the Swedish National Audit Office and the independent Fiscal Policy Council have called for fuller disclosure of public assets and liabilities. While the Budget Bill provides the annual budget constraint, Sweden faces a broader array of obligations, including those for social spending and aging in the long run, which deserve reflection in the annual accounts. Intertemporal net worth — which captures such obligations - constitutes the ultimate budget constraint; it should be nonnegative (Box 4).

\section{The authorities agreed that aging costs are key for fiscal sustainability. They} initially estimated aging costs on pensions, health, disability, unemployment, and education, to be 2.2 percent of GDP between 2004-50 (Figure 16). More recent estimates put this figure even lower. However, an independent staff evaluation suggests that comprehensive aging 
Figure 16: Sweden--Fiscal Policies Appear Sustainable if aging costs are at the lower bound of estimates; they would need adjustment at the upper bound of aging costs $1 /$

Real GDP is Projected to grow around 2 percent...

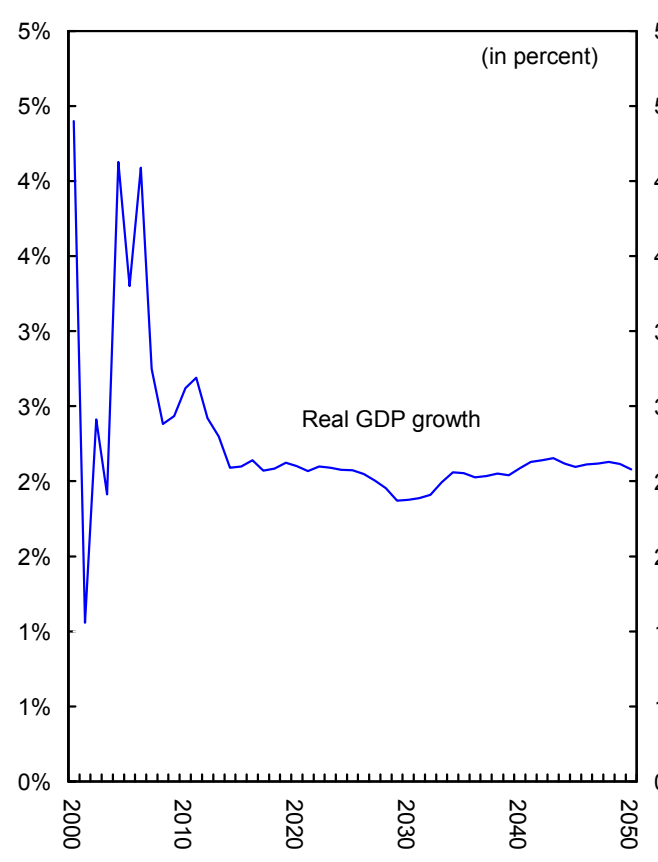

Fiscal expenditure depends on the estimate of aging costs $1 / \ldots$

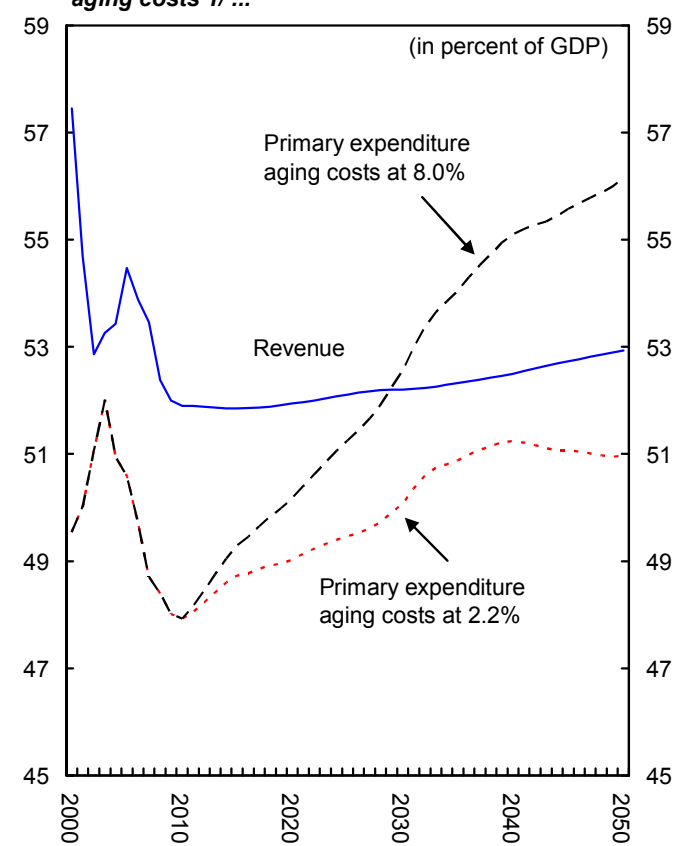

...with inflation at 2 percent and real interest rates

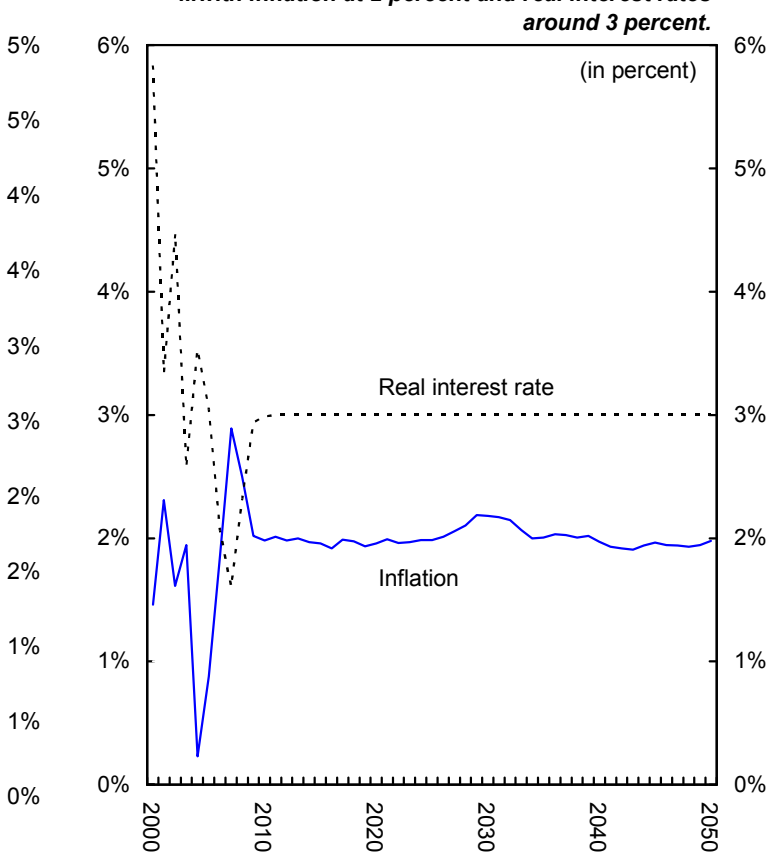

59

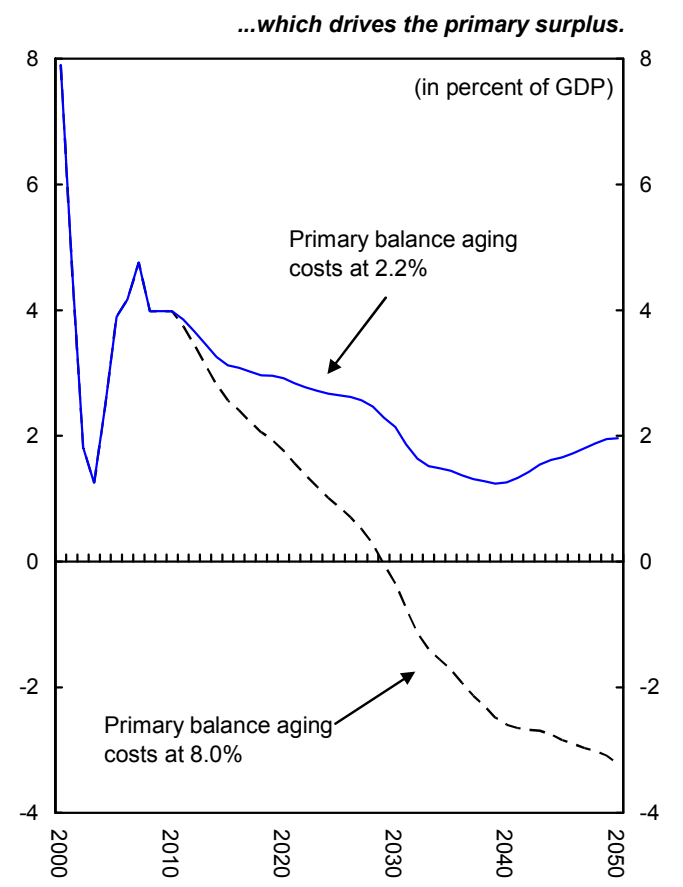

Source: Staff calculations based on information provided by the authorities.

$1 /$ Two scenarios represent primary expenditures with aging costs assumed to increase by 2.2 and 8.0 percent of GDP, respectively, between 2004-50. 
costs could be as high as 8.0 percent of GDP, reflecting higher health care inflation and lower productivity growth with aging. These differences are too large for comfort, and the staff recommended that the authorities request an independent evaluation of forecasting models and assumptions for long-term aging costs and fiscal projections. While long-term projections are invariably wide-ranging, monitoring them over time should lead to narrowing of differences and building comfort with the analysis and policy implications. The authorities concurred and would conduct further analysis.

\section{Box 4. A Preliminary Public Sector Balance Sheet ${ }^{6}$}

Current net worth. The balance sheet in Table 9 records assets and liabilities of the government. Sweden publishes data on financial assets and debt, but not on the public sector capital stock, which was estimated by the staff. Subtracting liabilities from assets yields government current net worth - public sector wealth. Sweden's is around 60 percent of GDP, higher than in most rich countries.

Forward-looking position. The public also needs information about forward looking policies, especially liabilities in the welfare system. To estimate the forward looking net position, the mission constructed a long-run potential output path and, with the inflation target, a long run nominal GDP path. This permits projecting long-run fiscal balances under current policies, and the evolution of assets, liabilities, and net worth. Net worth, 50 years hence, can be discounted to arrive at intertemporal net worth - the net worth in current krona that would result if current policies were maintained for 50 years, given expected demographics and aging costs.

Sweden's long run position is satisfactory if aging costs are contained. With low aging costs, the net worth constraint is amply met. With high aging costs, the net worth constraint is just met, but difficulties would emerge in due course. Given these wide-ranging estimates of aging costs, the results should be further analyzed by the authorities using their detailed data.

Financial net worth. It was agreed that further analysis is needed to assess whether a more restricted net worth concept, such as financial net worth (i.e. excluding nonmarketable/nonliquid assets) would be a better indicator of long run fiscal sustainability.

\footnotetext{
${ }^{6}$ See B. Traa: "Public Sector Balance Sheet" (PPP) on the Sweden country website: http://wwwintranet.imf.org/departments/EUR/CountryInfo/Sweden/Pages/2008ArtIV.aspx
} 


\section{Staff Appraisal}

38. The Swedish economy has performed well. Output and employment growth have been high, inflation has been moderate, the financial system is functioning well, public finances are solid, and the external position is favorable. Sweden has addressed demographic challenges with pension reform and now with labor supply measures.

39. The future also holds promise, subject to risk management. Now is the time to strengthen financial system resilience, before risks rise further. Inflation is ticking up, and monetary policy needs to be firm to anchor inflation expectations. Sweden has fiscal space, but contingencies in the public finances warrant monitoring.

40. Linkages between the financial system and the real economy are gaining importance. The recent financial turbulence has shown that markets can react to dents in confidence with high speed, thereby increasing credit costs and pinching off growth. This adds a premium to sound bank management, supervision, and regulation. Here too, Sweden has made progress - with four large banks emerging from the crisis of the early 1990s to become dominant players in the Swedish market, while diversifying in Scandinavian and Baltic neighbors and beyond. This strategy offers opportunities, but also requires tight risk management to minimize contingent claims on Swedish and foreign tax payers.

41. Market signals indicate increasing banking risks. Stock prices have dropped and credit default swap spreads have increased, particularly for banks active in the Baltics. Rating agencies, the Riksbank, FSA, and the banks themselves are confident that they are able to cope with adverse events, as shown in stress testing and internal risk models. Nevertheless, increased interconnectedness in financial systems can greatly accentuate the impact of shocks. With the strong current position, banks should bolster resilience, and the authorities need to cement their ability to deal with stress, should it come.

42. Sweden needs a dedicated remedial and resolution banking framework. The special provisions used to manage the banking crisis in the early 1990s are no longer in place. Markets are faster now, banks are larger, and regional cross-border dimensions add layers of complexity. The Ministry of Finance is working on a draft law that formalizes the resolution framework, and this effort should be completed rather sooner than later. Staff is mindful that such legislation requires close legal scrutiny, but more delays would increase vulnerabilities.

43. Sweden could benefit from an FSAP update. The authorities have made meaningful progress in addressing the 2002 FSAP recommendations, but some deficiencies remain given the growth and complexity of the financial system. An update appears opportune for identifying policy priorities to bolster further financial sector resilience.

\section{The krona is freely floating with its value determined daily by market demand} and supply. The current position of the krona provides Sweden with strong competitiveness. The staff expects the krona to appreciate gradually over the medium term, and the current account surplus to decline as the saving-investment balance gravitates to a longer-term equilibrium. A firmer krona would assist to lean against the wind of foreign price increases. 
45. The inflation targeting framework is working well. Nevertheless, with the jump in energy and food prices inflation has risen above the upper limit of the band, and indicators of core inflation and inflation expectations are picking up. Short-term pressures should not be allowed to seep into second-round effects.

46. Monetary policy should be biased upward. The repo interest rates is $4 \frac{1}{4}$ percentonly neutral despite rising imported inflation and inflation expectations. Since the mission visited Stockholm, inflation has increased further and a quarter point increase should be considered. Policy should not ease until inflation expectations clearly break and broad indicators of capacity use and economic activity trend down.

47. The fiscal performance continues to be impressive. For 2008, the authorities are on track to produce another sound surplus, with an approximately neutral fiscal impulse. The outlook for 2009 through 2011 continues to be favorable, especially in the official projections that assume some constant nominal appropriations.

48. Sweden has fiscal room to respond to a slowdown. The fiscal balance is running above 1 percent of GDP surplus over the cycle. With the economy likely dipping below potential next year, the staff supports reforms in the 2009 budget (not exceeding 1 percent of GDP) to cut taxes and to increase public investment in infrastructure, R\&D, and preschooling. These steps should aim at strengthening further long-run supply conditions.

\section{The authorities continue to pursue an ambitious structural reform program to} increase employment. Staff supports the thrust of these measures. Going forward, it would be important to limit distortions to benefit transparency in the tax and benefit system and reduce compliance costs. Evaluations of labor supply and demand measures by the authorities and stakeholders are welcome and warranted to track their impact on employment, hours worked, and different levels of government.

50. The government could include an intertemporal public sector balance sheet in the Budget Bills, updated on an annual basis. Sweden's demographic profile and aging costs appear modest in comparison with other high-income countries, and it may even be satisfying its long-run intertemporal budget constraint of positive net worth-few countries in the world have such an enviable position. Such a balance sheet would provide additional transparency into the fiscal position and forward-looking strategy, thereby enriching the public debate. The balance sheet should include alternative scenarios on long-run productivity, growth, and aging costs. An independent body could prepare estimates of aging costs, which are key parameters driving the long-run outlook.

51. It is recommended that Sweden remain on the 12-month Art. IV Consultation cycle. 
Table 1. Sweden: Selected Economic Indicators

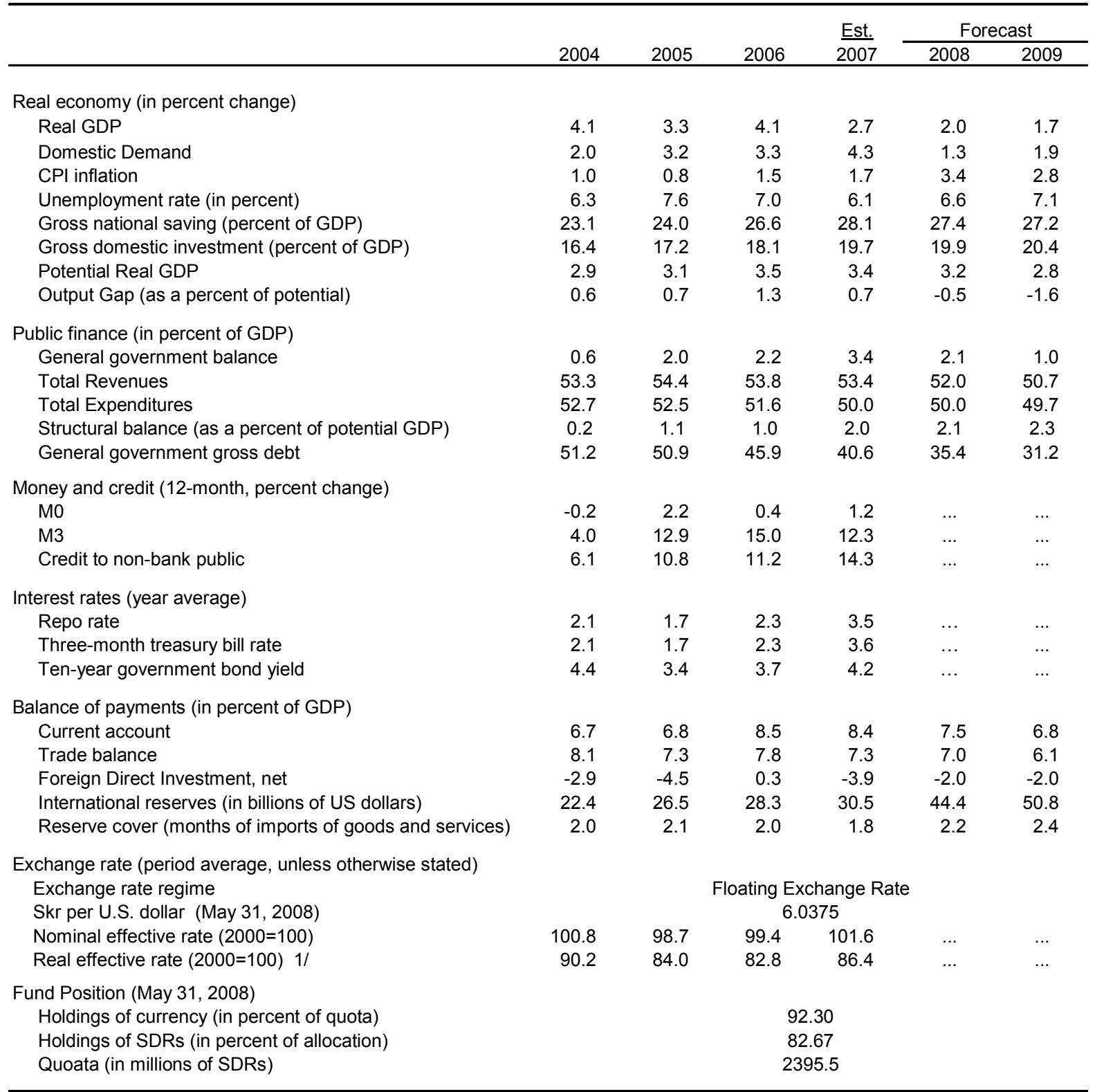

Sources: Statistics Sweden; Riksbank; Ministry of Finance; Datastream; INS; and IMF staff estimates.

$1 /$ Based on relative unit labor costs in manufacturing. 
Table 2. Sweden: Medium Term Scenario, 2006-13

\begin{tabular}{|c|c|c|c|c|c|c|c|c|}
\hline & \multirow[b]{2}{*}{2006} & \multirow{2}{*}{$\frac{\text { Est. }}{2007}$} & \multicolumn{6}{|c|}{ Forecast } \\
\hline & & & 2008 & 2009 & 2010 & 2011 & 2012 & 2013 \\
\hline & \multicolumn{8}{|c|}{ (in billions of 2000 krona) } \\
\hline Consumption & 1,874 & 1,918 & 1,958 & 2,000 & 2,053 & 2,107 & 2,161 & 2,214 \\
\hline Private & 1,262 & 1,300 & 1,324 & 1,358 & 1,403 & 1,452 & 1,500 & 1,546 \\
\hline Public & 615 & 622 & 634 & 642 & 649 & 655 & 661 & 668 \\
\hline Gross Fixed Investment & 486 & 525 & 547 & 554 & 591 & 628 & 659 & 685 \\
\hline Final Domestic Demand & 2,361 & 2,443 & 2,505 & 2,553 & 2,643 & 2,735 & 2,821 & 2,898 \\
\hline Changes in Inventories & 0 & 19 & -5 & -2 & 0 & 1 & 2 & 3 \\
\hline Total Domestic Demand & 2,367 & 2,468 & 2,500 & 2,551 & 2,643 & 2,736 & 2,823 & 2,901 \\
\hline Net Exports & 306 & 282 & 286 & 275 & 263 & 257 & 251 & 247 \\
\hline Exports & 1,433 & 1,519 & 1,607 & 1,645 & 1,716 & 1,802 & 1,889 & 1,973 \\
\hline Imports & 1,128 & 1,236 & 1,321 & 1,370 & 1,452 & 1,545 & 1,638 & 1,727 \\
\hline GDP & 2,657 & 2,729 & 2,784 & 2,831 & 2,911 & 2,998 & 3,082 & 3,160 \\
\hline & \multicolumn{8}{|c|}{ (percentage change) } \\
\hline Consumption & 2.1 & 2.3 & 1.9 & 2.2 & 2.7 & 2.7 & 2.6 & 2.4 \\
\hline Private & 2.5 & 3.0 & 1.9 & 2.6 & 3.3 & 3.5 & 3.3 & 3.0 \\
\hline Public & 1.5 & 1.1 & 1.9 & 1.3 & 1.2 & 0.9 & 1.0 & 0.9 \\
\hline Gross Fixed Investment & 7.7 & 8.0 & 4.1 & 1.2 & 6.7 & 6.3 & 4.9 & 3.9 \\
\hline Final Domestic Demand & 3.2 & 3.5 & 2.5 & 1.9 & 3.5 & 3.5 & 3.1 & 2.8 \\
\hline Changes in Inventories ${ }^{1}$ & 0.1 & 0.7 & -0.9 & 0.1 & 0.1 & 0.0 & 0.0 & 0.0 \\
\hline Total Domestic Demand & 3.4 & 4.3 & 1.3 & 2.1 & 3.6 & 3.5 & 3.2 & 2.8 \\
\hline Net Exports ${ }^{1}$ & 1.3 & -0.9 & 0.1 & -0.4 & -0.4 & -0.2 & -0.2 & -0.1 \\
\hline Exports & 8.9 & 6.0 & 5.8 & 2.4 & 4.3 & 5.0 & 4.8 & 4.5 \\
\hline Imports & 8.2 & 9.6 & 6.8 & 3.7 & 6.0 & 6.4 & 6.0 & 5.4 \\
\hline GDP & 4.1 & 2.7 & 2.0 & 1.7 & 2.8 & 3.0 & 2.8 & 2.5 \\
\hline \multicolumn{9}{|l|}{ Memoradum items: } \\
\hline \multicolumn{9}{|l|}{ Potential GDP } \\
\hline in billions of 2000 kroner & 2,622 & 2,711 & 2,799 & 2,879 & 2,955 & 3,028 & 3,095 & 3,160 \\
\hline percentage change & 3.5 & 3.4 & 3.2 & 2.8 & 2.7 & 2.5 & 2.2 & 2.1 \\
\hline Output Gap (as a percent of potential) & 1.3 & 0.7 & -0.5 & -1.6 & -1.5 & -1.0 & -0.4 & 0.0 \\
\hline
\end{tabular}

${ }^{1}$ Contributions to growth 


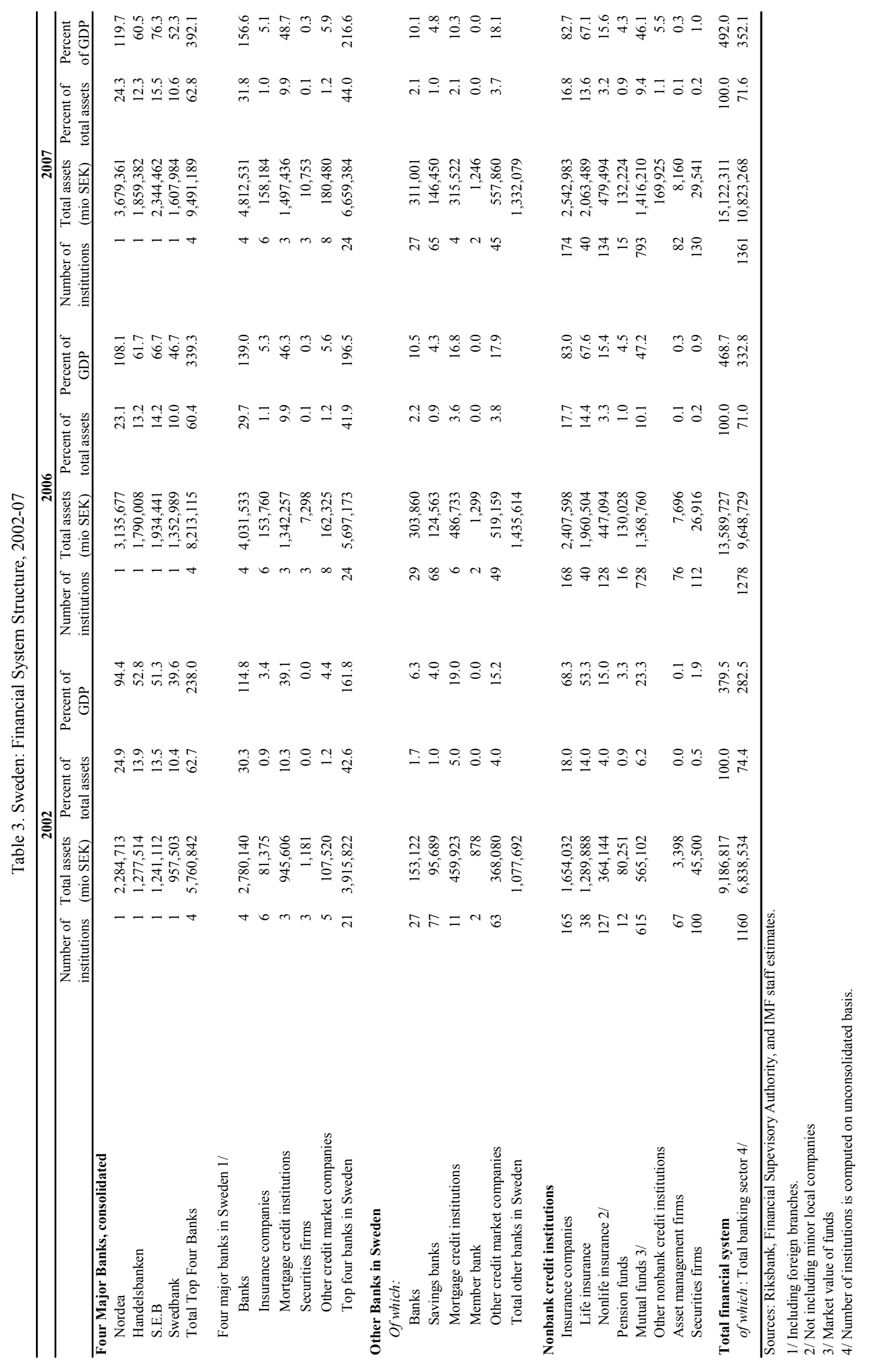


Table 4. Sweden: Financial Soundness Indicators: Banks, 2003-07 (end-period, in percentage)

\begin{tabular}{|c|c|c|c|c|c|}
\hline & 2003 & 2004 & 2005 & 2006 & 2007 \\
\hline \multicolumn{6}{|l|}{$\overline{\text { Capital Adequacy }}$} \\
\hline Regulatory capital to risk-weighted assets 1 / & 10.5 & 10.6 & 10.5 & 10.5 & 10.2 \\
\hline of which: Four major banks & 10.0 & 10.1 & 10.1 & 10.0 & 9.8 \\
\hline Regulatory Tier I capital to risk-weighted assets 1 / & 8.0 & 8.3 & 7.7 & 7.8 & 7.5 \\
\hline of which: Four major banks & 7.4 & 7.6 & 7.0 & 7.1 & 7.0 \\
\hline Capital as percent of assets (leverage ratio) & 5.1 & 4.8 & 4.8 & 4.8 & 4.7 \\
\hline of which: Four major banks & 5.0 & 4.8 & 4.8 & 4.9 & 4.7 \\
\hline \multicolumn{6}{|l|}{ Asset quality and exposure } \\
\hline Nonperforming loans to total gross loans & 2.0 & 1.2 & 0.9 & 0.8 & 0.6 \\
\hline of which: Four major banks & 1.9 & 1.1 & 0.8 & 0.8 & 0.6 \\
\hline Nonperforming loans net of loan-loss provisions to capital & 11.9 & 4.8 & 3.1 & 4.3 & 3.4 \\
\hline of which: Four major banks & 11.5 & 4.0 & 2.7 & 3.9 & 3.1 \\
\hline \multicolumn{6}{|l|}{ Sectoral distribution of bank credit to the private sector (percent) } \\
\hline of which: Total real estate loans in percent of total loans $2 /$ & $\ldots$ & 18.7 & 18.0 & 17.7 & 18.2 \\
\hline Sweden & 57.2 & 56.7 & 53.8 & 54.0 & 53.2 \\
\hline Nonfinancial corporations & 24.3 & 23.2 & 21.8 & 20.6 & 20.7 \\
\hline Households & 21.5 & 22.1 & 20.6 & 20.6 & 19.3 \\
\hline Small personal companies & 6.5 & 6.6 & 6.4 & 6.3 & 6.3 \\
\hline Insurance companies & 0.4 & 0.4 & 0.5 & 0.5 & 0.8 \\
\hline Other & 4.6 & 4.3 & 4.5 & 6.0 & 6.2 \\
\hline Outside Sweden & 42.8 & 43.3 & 46.2 & 46.0 & 46.8 \\
\hline Large exposures as percent of tier 1 capital & 26.4 & 11.1 & 17.5 & 18.3 & 13.4 \\
\hline of which: Four major banks & 22.2 & 12.4 & 12.0 & 13.3 & 6.5 \\
\hline \multicolumn{6}{|l|}{ Earnings and profitability } \\
\hline Return on assets (Net income as percent of average total assets) & 0.6 & 0.7 & 0.8 & 0.8 & 0.8 \\
\hline of which: Four major banks & 0.6 & 0.7 & 0.7 & 0.8 & 0.8 \\
\hline Return on equity (Net income as percent of average equity capital) & 12.5 & 15.9 & 18.1 & 19.9 & 18.5 \\
\hline of which: Four major banks & 13.3 & 16.0 & 18.7 & 21.0 & 19.7 \\
\hline Net interest income as percent of gross income & 64.4 & 58.9 & 52.4 & 49.2 & 52.4 \\
\hline of which: Four major banks & 64.6 & 59.2 & 52.6 & 49.4 & 52.7 \\
\hline Trading income and foreign exchange gains (losses) to gross income & 3.0 & 5.1 & 9.6 & 10.5 & 8.3 \\
\hline of which: Four major banks & 3.5 & 5.4 & 10.0 & 11.2 & 9.6 \\
\hline Personnel expenses as percent of noninterest expenses & 54.0 & 53.7 & 56.0 & 57.4 & 57.1 \\
\hline of which: Four major banks & 55.9 & 55.7 & 58.4 & 60.3 & 60.0 \\
\hline \multicolumn{6}{|l|}{ Liquidity } \\
\hline Liquid assets as percent of total assets & 4.4 & 5.2 & 5.0 & 5.0 & 5.0 \\
\hline of which : Four major banks & 4.4 & 5.3 & 4.6 & 5.1 & 5.4 \\
\hline Liquid assets as percent of short-term liabilities & 29.3 & 30.6 & 31.6 & 32.1 & 34.1 \\
\hline of which: Four major banks & 32.1 & 34.7 & 33.3 & 37.5 & 43.8 \\
\hline Customer deposits as a percent of total (non-interbank) loans & 50.6 & 52.6 & 50.2 & 53.8 & 51.4 \\
\hline of which: Four major banks & 49.1 & 50.8 & 49.1 & 53.4 & 51.3 \\
\hline Noninterbank loans to noninterbank deposits & 142.6 & 130.8 & 137.4 & 135.7 & 139.8 \\
\hline of which: Four major banks & 150.2 & 139.6 & 145.1 & 143.1 & 148.4 \\
\hline \multicolumn{6}{|l|}{ Foreign exchange risk } \\
\hline Foreign currency-denominated loans as percent of total loans & 30.0 & 28.0 & 32.3 & 34.6 & 36.0 \\
\hline Foreign currency-denominated assets as percent of total assets & 33.2 & 36.6 & 38.4 & 38.2 & 39.5 \\
\hline \multicolumn{6}{|l|}{ Exposure to derivatives } \\
\hline Gross asset position in derivatives as percent of tier 1 capital & 152.6 & 176.7 & 164.7 & 110.7 & 132.0 \\
\hline Gross liability position in derivatives as percent of tier 1 capital & 168.2 & 188.5 & 165.2 & 117.3 & 136.1 \\
\hline
\end{tabular}

Sources: Financial Supervisory Authority, Riksbank, and IMF staff estimates.

1/ From 2007, under Basel II, actual reported above/below capital requirement ( 8 percent); computed here in percent of risk-weighted assets for consistency purposes.

2/ On consolidated basis 
Table 5. Sweden: Financial Soundness Indicators: Non-Banks, 2003-07

(end-period, in percentage)

\begin{tabular}{|c|c|c|c|c|c|}
\hline & 2003 & 2004 & 2005 & 2006 & 2007 \\
\hline \multicolumn{6}{|l|}{ Insurance sector } \\
\hline \multicolumn{6}{|l|}{ Solvency ratio (margin/required margin) } \\
\hline Life insurance companies & 9.0 & 8.4 & 11.2 & 13.8 & 14.9 \\
\hline Non-life insurance companies & 6.5 & 5.1 & 7.7 & 8.5 & 9.5 \\
\hline \multicolumn{6}{|l|}{ Households } \\
\hline Household debt to banks as percent of GDP & 59.2 & 62.1 & 66.2 & 69.2 & 71.7 \\
\hline Household debt service and principal payments as percent to income & 3.8 & 3.5 & 3.4 & 3.6 & 4.4 \\
\hline \multicolumn{6}{|l|}{ Corporate sector } \\
\hline Debt stock as percent of GDP & 47.5 & 45.6 & 48.3 & 49.1 & 55.1 \\
\hline Total debt to equity (percent, without financial corporations) & 159.2 & 147.8 & 142.5 & 135.6 & 148.2 \\
\hline \multicolumn{6}{|l|}{ Equity risk } \\
\hline Equity prices (OM Stockhom Stock Exchange Index) (y-o-y change, price retu] & 29.8 & 17.6 & 32.6 & 23.6 & -6.0 \\
\hline Equity prices of financial institutions (y-o-y change, price return) & 37.1 & 20.8 & 23.1 & 21.2 & -9.3 \\
\hline \multicolumn{6}{|l|}{ Market capitalization in percent of GDP } \\
\hline \multicolumn{6}{|l|}{ Real estate markets (prices y-o-y change) } \\
\hline One- or two dwelling buildings & 6.6 & 9.6 & 9.6 & 11.4 & 10.7 \\
\hline Buildings for seasonal and secondary use & 7.0 & 10.7 & 10.8 & 12.1 & 11.4 \\
\hline Multi-dwelling and commercial buildings & 3.6 & 12.0 & 5.1 & 7.6 & 9.1 \\
\hline Residential real estate prices & 6.1 & 10.0 & 10.5 & 10.5 & 11.3 \\
\hline Commercial real estate prices & -11.7 & -3.8 & 17.6 & 30.0 & 9.0 \\
\hline \multicolumn{6}{|l|}{ Memorandum items } \\
\hline GDP (y-o-y change, constant prices) & 1.9 & 4.1 & 3.3 & 4.1 & 2.6 \\
\hline GDP bn SEK, current prices & $2,515.2$ & $2,625.0$ & $2,735.2$ & $2,899.7$ & $3,073.8$ \\
\hline Total financial sector assets (bn SEK) & $\ldots$ & $\ldots$ & $\ldots$ & $13,589.7$ & $15,122.3$ \\
\hline of which: four major banks (in percent of total financial assets) & $\ldots$ & $\ldots$ & $\ldots$ & 71.0 & 71.6 \\
\hline Total financial sector assets (in percent of GDP) & $\ldots$ & $\ldots$ & $\ldots$ & 468.7 & 492.0 \\
\hline of which: four major banks (in percent of GDP) & $\ldots$ & $\ldots$ & $\ldots$ & 332.8 & 352.1 \\
\hline
\end{tabular}


Table 6. Sweden: Balance of Payments Accounts, 2006-13

\begin{tabular}{|c|c|c|c|c|c|c|c|c|}
\hline & \multirow[b]{2}{*}{2006} & \multirow{2}{*}{$\frac{\text { Est. }}{2007}$} & \multicolumn{6}{|c|}{ Forecast } \\
\hline & & & 2008 & 2009 & 2010 & 2011 & 2012 & 2013 \\
\hline & \multicolumn{8}{|c|}{ (in billions of krona) } \\
\hline Current Account Balance & 245 & 256 & 244 & 230 & 224 & 227 & 233 & 244 \\
\hline Trade Balance & 225 & 223 & 226 & 205 & 186 & 174 & 165 & 160 \\
\hline Exports of G\&S & 1,462 & 1,570 & 1,709 & 1,766 & 1,822 & 1,911 & 2,017 & 2,128 \\
\hline Imports of G\&S & 1,237 & 1,348 & 1,483 & 1,560 & 1,636 & 1,736 & 1,852 & 1,969 \\
\hline Factor income, net & 54 & 67 & 56 & 64 & 80 & 97 & 114 & 132 \\
\hline Current Transfers, net & -34 & -34 & -38 & -40 & -41 & -44 & -46 & -48 \\
\hline Financial Account Balance & -253 & -154 & -242 & -227 & -222 & -225 & -231 & -241 \\
\hline Investment Abroad ${ }^{1,2}$ & -594 & -649 & -285 & -272 & -269 & -274 & -283 & -295 \\
\hline o/w Reserves & -11 & 2 & -63 & -41 & -26 & -19 & -15 & -15 \\
\hline \multirow[t]{2}{*}{ Investment in Sweden ${ }^{1}$} & 341 & 495 & 43 & 45 & 47 & 50 & 52 & 55 \\
\hline & \multicolumn{8}{|c|}{ (as a percent of GDP) } \\
\hline Current Account Balance & 8.5 & 8.4 & 7.5 & 6.8 & 6.3 & 6.1 & 6.0 & 6.0 \\
\hline Trade Balance & 7.8 & 7.3 & 7.0 & 6.1 & 5.2 & 4.7 & 4.2 & 3.9 \\
\hline Exports of G\&S & 50.4 & 51.1 & 52.8 & 52.1 & 51.3 & 51.2 & 51.6 & 52.0 \\
\hline Imports of G\&S & 42.7 & 43.9 & 45.8 & 46.1 & 46.1 & 46.6 & 47.4 & 48.1 \\
\hline Factor income, net & 1.9 & 2.2 & 1.7 & 1.9 & 2.3 & 2.6 & 2.9 & 3.2 \\
\hline Current Transfers, net & -1.2 & -1.1 & -1.2 & -1.2 & -1.2 & -1.2 & -1.2 & -1.2 \\
\hline Financial Account Balance & -8.7 & -5.0 & -7.5 & -6.7 & -6.2 & -6.0 & -5.9 & -5.9 \\
\hline Investment Abroad $^{1,2}$ & -20.5 & -21.1 & -8.8 & -8.0 & -7.6 & -7.4 & -7.2 & -7.2 \\
\hline Direct Investment & -5.6 & -8.1 & -5.9 & -5.9 & -5.9 & -5.9 & -5.9 & -5.9 \\
\hline Portfolio Investment & -8.6 & -11.0 & -6.5 & -6.5 & -6.5 & -6.5 & -6.5 & -6.5 \\
\hline Other Investment & -13.3 & -10.8 & -5.1 & -5.1 & -5.1 & -5.1 & -5.1 & -5.1 \\
\hline Reserves & -0.4 & 0.1 & -2.0 & -1.2 & -0.7 & -0.5 & -0.4 & -0.4 \\
\hline Investment in Sweden ${ }^{1}$ & 11.7 & 16.1 & 1.3 & 1.3 & 1.3 & 1.3 & 1.3 & 1.3 \\
\hline Direct Investment & 5.9 & 4.1 & 3.9 & 3.9 & 3.9 & 3.9 & 3.9 & 3.9 \\
\hline Portfolio Investment & 3.4 & 13.2 & 3.3 & 3.3 & 3.3 & 3.3 & 3.3 & 3.3 \\
\hline Other Investment & 9.8 & 7.6 & 5.1 & 5.1 & 5.1 & 5.1 & 5.1 & 5.1 \\
\hline \multirow[t]{2}{*}{ Errors and Omissions } & 0.9 & -3.3 & 0.0 & 0.0 & 0.0 & 0.0 & 0.0 & 0.0 \\
\hline & \multicolumn{8}{|c|}{ (percentage change) } \\
\hline \multicolumn{9}{|l|}{ Exports of G\&S } \\
\hline Value & 12.3 & 7.4 & 8.9 & 3.3 & 3.2 & 4.9 & 5.6 & 5.5 \\
\hline Volume & 9.4 & 5.4 & 5.8 & 2.3 & 4.3 & 5.0 & 4.8 & 4.5 \\
\hline Deflator & 2.7 & 1.9 & 2.9 & 0.9 & -1.1 & -0.1 & 0.8 & 1.0 \\
\hline \multicolumn{9}{|l|}{ Imports of G\&S } \\
\hline Value & 12.1 & 9.0 & 10.1 & 5.2 & 4.8 & 6.1 & 6.7 & 6.3 \\
\hline Volume & 8.5 & 8.9 & 7.0 & 3.7 & 6.0 & 6.3 & 6.0 & 5.4 \\
\hline Deflator & 3.3 & 0.1 & 2.9 & 1.4 & -1.1 & -0.2 & 0.6 & 0.8 \\
\hline
\end{tabular}

${ }^{1}$ Includes investments in financial derivatives.

${ }^{2}$ Positive number indicates an accumulation of foreign assets. 
Table 7. Sweden: International Investment Position, 2006-13

\begin{tabular}{|c|c|c|c|c|c|c|c|c|}
\hline & \multirow[b]{2}{*}{2006} & \multirow{2}{*}{$\begin{array}{l}\text { Est. } \\
2007\end{array}$} & \multicolumn{6}{|c|}{ Forecast } \\
\hline & & & 2008 & 2009 & 2010 & 2011 & 2012 & 2013 \\
\hline & \multicolumn{8}{|c|}{ (in billions of krona) } \\
\hline Swedish Assets Abroad ${ }^{1}$ & 6,312 & 7,276 & 7,989 & 8,639 & 9,306 & 9,998 & 10,718 & 11,470 \\
\hline o/w Official Reserves & 208 & 206 & 269 & 310 & 336 & 355 & 370 & 385 \\
\hline Swedish Liabilities Abroad ${ }^{1}$ & 6,666 & 7,490 & 7,978 & 8,414 & 8,872 & 9,354 & 9,858 & 10,385 \\
\hline International Investment Position & -354 & -215 & 11 & 225 & 434 & 644 & 860 & 1,086 \\
\hline & \multicolumn{8}{|c|}{ (as a percent of GDP) } \\
\hline Swedish Assets Abroad ${ }^{1}$ & 217.7 & 236.9 & 246.7 & 255.2 & 262.1 & 268.1 & 274.1 & 280.5 \\
\hline Direct investments & 61.3 & 65.9 & 68.4 & 71.3 & 73.9 & 76.3 & 78.6 & 81.1 \\
\hline Portfolio investments & 88.6 & 94.6 & 96.2 & 98.6 & 100.5 & 102.2 & 103.9 & 105.9 \\
\hline Equity securities & 60.0 & 64.1 & 65.2 & 66.8 & 68.1 & 69.2 & 70.4 & 71.8 \\
\hline Debt securities & 28.6 & 30.5 & 31.0 & 31.8 & 32.4 & 32.9 & 33.5 & 34.1 \\
\hline Other Investment & 53.3 & 61.1 & 63.0 & 65.4 & 67.5 & 69.4 & 71.3 & 73.3 \\
\hline Reserve assets & 7.2 & 6.7 & 8.3 & 9.2 & 9.5 & 9.5 & 9.5 & 9.4 \\
\hline Swedish Liabilities Abroad ${ }^{1}$ & 229.9 & 243.9 & 246.4 & 248.5 & 249.9 & 250.8 & 252.1 & 253.9 \\
\hline Direct investments & 52.9 & 54.1 & 55.2 & 56.7 & 58.0 & 59.1 & 60.3 & 61.5 \\
\hline Portfolio investments & 105.8 & 113.1 & 110.6 & 109.1 & 107.4 & 105.6 & 104.0 & 102.8 \\
\hline Equity securities & 35.7 & 38.2 & 37.4 & 36.9 & 36.3 & 35.7 & 35.2 & 34.8 \\
\hline Debt securities & 70.0 & 74.9 & 73.2 & 72.2 & 71.1 & 69.9 & 68.9 & 68.1 \\
\hline Other Investment & 63.8 & 67.9 & 69.5 & 71.6 & 73.4 & 75.0 & 76.7 & 78.5 \\
\hline International Investment Position & -12.2 & -7.0 & 0.3 & 6.7 & 12.2 & 17.3 & 22.0 & 26.5 \\
\hline \multicolumn{9}{|l|}{ Memorandum: } \\
\hline \multicolumn{9}{|l|}{ Implied Rates of Return on: } \\
\hline Swedish Direct Investments & 15.1 & 15.0 & 14.1 & 13.1 & 13.1 & 13.1 & 13.1 & 13.1 \\
\hline Swedish Equity Investments & 2.8 & 3.2 & 2.6 & 2.6 & 2.6 & 2.6 & 2.6 & 2.6 \\
\hline Swedish Debt Investments & 4.7 & 5.1 & 4.5 & 4.5 & 4.5 & 4.5 & 4.5 & 4.5 \\
\hline Other Swedish Investments & 4.1 & 4.0 & 3.3 & 3.3 & 3.3 & 3.3 & 3.3 & 3.3 \\
\hline Swedish Reserve Assets & 2.2 & 2.2 & 2.2 & 2.2 & 2.2 & 2.2 & 2.2 & 2.2 \\
\hline Direct Investments in Sweden & 10.4 & 10.5 & 10.2 & 10.2 & 10.2 & 10.2 & 10.2 & 10.2 \\
\hline Portfolio Investments in Sweden & 3.3 & 4.9 & 4.2 & 3.2 & 3.2 & 3.2 & 3.2 & 3.2 \\
\hline Other Investments in Sweden & 4.3 & 3.8 & 4.4 & 4.4 & 4.4 & 4.4 & 4.4 & 4.4 \\
\hline
\end{tabular}

${ }^{1}$ Includes investments in financial derivatives. 
Table 8. Sweden: General Government Financial Accounts, 2006-13

\begin{tabular}{|c|c|c|c|c|c|c|c|c|}
\hline & \multicolumn{2}{|r|}{ Est. } & \multicolumn{6}{|c|}{ Staff Forecast } \\
\hline & 2006 & 2007 & 2008 & 2009 & 2010 & 2011 & 2012 & 2013 \\
\hline & \multicolumn{8}{|c|}{ (in billions of krona) } \\
\hline Total Revenue & 1,560 & 1,640 & 1,685 & 1,716 & 1,801 & 1,901 & 2,002 & 2,101 \\
\hline Direct Taxes & 575 & 584 & 568 & 571 & 601 & 639 & 680 & 718 \\
\hline Indirect Taxes & 485 & 513 & 583 & 596 & 625 & 657 & 689 & 720 \\
\hline Social Security Contributions & 352 & 374 & 355 & 361 & 379 & 398 & 417 & 436 \\
\hline Capital income & 61 & 72 & 76 & 79 & 83 & 87 & 91 & 96 \\
\hline Other income & 87 & 97 & 103 & 108 & 113 & 119 & 125 & 131 \\
\hline Total Expenditure & 1,496 & 1,535 & 1,616 & 1,683 & 1,752 & 1,822 & 1,897 & 1,970 \\
\hline Current Transfers & 599 & 591 & 618 & 638 & 665 & 695 & 729 & 762 \\
\hline Consumption & 762 & 796 & 849 & 892 & 930 & 967 & 1,006 & 1,046 \\
\hline Investment & 83 & 91 & 96 & 101 & 105 & 111 & 116 & 121 \\
\hline Interest Payments & 53 & 57 & 53 & 52 & 52 & 50 & 46 & 41 \\
\hline Primary balance & 116 & 162 & 123 & 85 & 101 & 128 & 151 & 172 \\
\hline Overall Balance & 63 & 105 & 69 & 33 & 49 & 79 & 105 & 131 \\
\hline Central government & 25 & 68 & 39 & 18 & 39 & -- & -- & -- \\
\hline Pension system & 30 & 33 & 24 & 17 & 12 & -- & -- & -- \\
\hline \multirow[t]{2}{*}{ Local governments } & 9 & 4 & 6 & -2 & -1 & -- & -- & -- \\
\hline & \multicolumn{8}{|c|}{ (as a percent of GDP) } \\
\hline Total Revenue & 53.8 & 53.4 & 52.0 & 50.7 & 50.7 & 51.0 & 51.2 & 51.4 \\
\hline Direct Taxes & 19.8 & 19.0 & 17.5 & 16.9 & 16.9 & 17.1 & 17.4 & 17.6 \\
\hline Indirect Taxes & 16.7 & 16.7 & 18.0 & 17.6 & 17.6 & 17.6 & 17.6 & 17.6 \\
\hline Social Security Contributions & 12.1 & 12.2 & 11.0 & 10.7 & 10.7 & 10.7 & 10.7 & 10.7 \\
\hline Capital income & 2.1 & 2.3 & 2.3 & 2.3 & 2.3 & 2.3 & 2.3 & 2.3 \\
\hline Total Expenditure & 51.6 & 50.0 & 49.9 & 49.7 & 49.4 & 48.8 & 48.5 & 48.2 \\
\hline Current Transfers & 20.7 & 19.2 & 19.1 & 18.8 & 18.7 & 18.6 & 18.6 & 18.6 \\
\hline Consumption & 26.3 & 25.9 & 26.2 & 26.4 & 26.2 & 25.9 & 25.7 & 25.6 \\
\hline Investment & 2.9 & 3.0 & 3.0 & 3.0 & 3.0 & 3.0 & 3.0 & 3.0 \\
\hline Interest Payments & 1.8 & 1.9 & 1.6 & 1.5 & 1.5 & 1.3 & 1.2 & 1.0 \\
\hline Primary balance & 4.0 & 5.3 & 3.8 & 2.5 & 2.8 & 3.4 & 3.9 & 4.2 \\
\hline Overall Balance & 2.2 & 3.4 & 2.1 & 1.0 & 1.4 & 2.1 & 2.7 & 3.2 \\
\hline Central government & 0.8 & 2.2 & 1.2 & 0.5 & 1.1 & -- & -- & -- \\
\hline Pension system & 1.0 & 1.1 & 0.7 & 0.5 & 0.3 & -- & -- & -- \\
\hline Local governments & 0.3 & 0.1 & 0.2 & 0.0 & 0.0 & -- & -- & -- \\
\hline Structural Balance & 1.0 & 2.0 & 2.2 & 2.3 & 2.5 & 2.9 & 3.0 & 3.2 \\
\hline Fiscal Impulse (expansionary +) & 0.0 & -1.0 & -0.1 & -0.1 & -0.3 & -0.3 & -0.1 & -0.2 \\
\hline \multicolumn{9}{|l|}{ Memorandum items: } \\
\hline Gross Public Debt (percent of GDP) & 45.9 & 40.6 & 36.4 & 33.8 & 30.9 & 27.3 & 23.3 & 19.1 \\
\hline Nomimal GDP (in billions of SEK) & 2,900 & 3,071 & 3,238 & 3,386 & 3,550 & 3,730 & 3,911 & 4,090 \\
\hline
\end{tabular}

Sources: 2008 Fiscal Policy Bill (Spring 2008) and IMF staff estimates. 
Table 9. Sweden: Public Sector Balance Sheet

\begin{tabular}{|c|c|c|c|c|c|c|}
\hline \multirow[b]{2}{*}{ Aging costs (percent of GDP) } & \multirow[t]{2}{*}{2003} & \multirow[t]{2}{*}{2004} & \multirow[t]{2}{*}{2005} & \multirow[t]{2}{*}{2006} & \multicolumn{2}{|c|}{$20071 /$} \\
\hline & & & & & 2.2 & 8.0 \\
\hline \multicolumn{7}{|c|}{ (In billions of SEK) } \\
\hline Assets & 2,610 & 2,754 & 2,995 & 3,307 & 3,466 & 3,466 \\
\hline Financial assets & 1,534 & 1,662 & 1,870 & 2,114 & 2,205 & 2,205 \\
\hline Cash \& ST securities & 57 & 63 & 72 & 87 & 90 & 90 \\
\hline Equity and mutual funds & 725 & 784 & 920 & 1,066 & 1,127 & 1,127 \\
\hline Other & 752 & 815 & 878 & 961 & 988 & 988 \\
\hline Capital stock net of depreciation & 1,076 & 1,092 & 1,125 & 1,193 & 1,261 & 1,261 \\
\hline Liabilities & 1,618 & 1,680 & 1,762 & 1,657 & 1,588 & 1,588 \\
\hline Financial liabilities & 1,618 & 1,680 & 1,762 & 1,657 & 1,588 & 1,588 \\
\hline Gross debt & 1,315 & 1,345 & 1,393 & 1,331 & 1,244 & 1,244 \\
\hline Other & 303 & 335 & 369 & 326 & 344 & 344 \\
\hline Current net worth & 992 & 1,074 & 1,233 & 1,650 & 1,878 & 1,878 \\
\hline NPV of future fiscal policies (50 years) $2 /$ & 1,989 & 2,046 & 2,034 & 1,788 & 1,752 & $-1,776$ \\
\hline Intertemporal net worth & 2,981 & 3,120 & 3,267 & 3,438 & 3,630 & 102 \\
\hline Intertemporal financial net worth $3 /$ & 1,905 & 2,028 & 2,142 & 2,245 & 2,369 & $-1,159$ \\
\hline \multicolumn{7}{|c|}{ (In percent of GDP) } \\
\hline Assets & 103.8 & 104.9 & 109.5 & 114.0 & 112.8 & 112.8 \\
\hline Financial assets & 61.0 & 63.3 & 68.4 & 72.9 & 71.7 & 71.7 \\
\hline Cash \& ST securities & 2.3 & 2.4 & 2.6 & 3.0 & 2.9 & 2.9 \\
\hline Equity and mutual funds & 28.8 & 29.9 & 33.6 & 36.8 & 36.7 & 36.7 \\
\hline Other & 29.9 & 31.0 & 32.1 & 33.1 & 32.1 & 32.1 \\
\hline Capital stock net of depreciation & 42.8 & 41.6 & 41.1 & 41.1 & 41.0 & 41.0 \\
\hline Liabilities & 64.3 & 64.0 & 64.4 & 57.1 & 51.7 & 51.7 \\
\hline Financial liabilities & 64.3 & 64.0 & 64.4 & 57.1 & 51.7 & 51.7 \\
\hline Gross debt & 52.3 & 51.2 & 50.9 & 45.9 & 40.5 & 40.5 \\
\hline Other & 12.0 & 12.8 & 13.5 & 11.2 & 11.2 & 11.2 \\
\hline Current net worth & 39.4 & 40.9 & 45.1 & 56.9 & 61.1 & 61.1 \\
\hline NPV of future fiscal policies (50 years) $2 /$ & 79.1 & 77.9 & 74.4 & 61.7 & 57.0 & -57.8 \\
\hline Intertemporal net worth & 118.5 & 118.9 & 119.4 & 118.6 & 118.1 & 3.3 \\
\hline Intertemporal financial net worth $3 /$ & 75.7 & 77.3 & 78.3 & 77.4 & 77.1 & -37.7 \\
\hline \multicolumn{7}{|l|}{ Memorandum items: } \\
\hline GDP (SEK billions) & 2,515 & 2,625 & 2,735 & 2,900 & 3,074 & 3,074 \\
\hline
\end{tabular}

Source: Swedisch authorities; and Fund staff calculations.

1/ Two scenarios: one with aging costs of 2.2 percent of GDP through 2050; and a second with aging costs of 8.0 percent of GDP through 2050.

2/ Stream of discounted projected future primary fiscal balances under current policies and with the indicated aging costs. Discount rate is the average cost of government funding.

$3 /$ Considers only financial assets and liabilities (i.e. excludes capital stock). This measure is a liquidity indicator whereas the comprehensive net worth is a solvency indicator. 


\section{APPENDIX I. SWEDEN: FUnd RELATIONS}

(As of May 31, 2008)

I. Membership Status: Joined 08/31/1951

$\underline{\text { Article VIII }}$

II. General Resources Account:

SDR Million

Quota

Fund holdings of currency

Reserve position

III. SDR Department:

Net cumulative allocation

Holdings
$2,395.50$

$2,111.15$

184.35

SDR Million

246.53

203.79

\section{Percent of Quota}

100.00

92.30

7.70

Percent of Allocation

100.00

82.67

IV. Outstanding Purchases and Loans: None

V. Financial Arrangements: None

VI. Projected Obligations to Fund: ${ }^{1 /}$

(SDR Million; based on existing use of resources and present holdings of SDRs):

Forthcoming
\begin{tabular}{lllll}
$2008 \quad 2009$ & $2010 \quad 2011$ & 2012 \\
\hline
\end{tabular}

Principal

Charges/Interest

Total

$\begin{array}{lllll}\frac{0.62}{0.62} & \frac{1.29}{1.29} & \frac{1.29}{1.29} & \frac{1.29}{1.29} & \frac{1.29}{1.29}\end{array}$

${ }^{1 /}$ When a member has overdue financial obligations outstanding for more than three months, the amount of such arrears will be shown in this section.

VII. Exchange Arrangements: The Krona has been floating freely since November 19, 1992. Sweden has accepted the obligations of Article VIII (Sections 2(a), 3, and 4) and maintains an exchange system free of restrictions on payments and transfers for current international transactions, apart from those imposed for security reasons, as notified to the Fund by the Riksbank (EBD/06/79, June 23, 2006) in accordance with Executive Board Decision No.144-(52/51). 
VIII. 2008 Article IV Consultation: A staff team comprising B. Traa (head, EUR), A. Brunner (EUR), A. Maechler (MCM), and A. Jousten (FAD) visited Stockholm during May 23-June 2, 2008 to conduct the consultation discussions. Mr. Henriksson, Sweden's Executive Director, attended some meetings.

Outreach: The team met with the labor federation, the employers association of industry, the four largest banks, think tanks, members of the Riksdag Finance Committee, and the Fiscal Policy Council.

Press conference: The mission held a press conference in the Riksbank after the concluding meeting.

Publication: The staff report will be published.

Last Article IV Consultation: Discussions for the 2007 Article IV consultation were held in Stockholm on November 7-14, 2006 and the staff report was issued on February 7, 2007 (IMF Country Report 07/52). The consultation was concluded by the Executive Board on January 26, 2007.

IX. Technical Assistance: In connection with the 2007 Article IV consultation, LEG and MCM provided technical assistance on bank resolution frameworks (Aide Memoire, March 16, 2007).

X. Resident Representative: None 


\section{Statement by the IMF Staff Representative August 1, 2008}

1. This statement provides information that has become available since the circulation of the staff report for the 2008 Article IV Consultation. It does not alter the thrust of the staff appraisal.

2. Inflation rose to 4.3 percent in June (higher than expected by the authorities, staff, and other analysts), and is now at its highest level since the mid-1990s.

3. Monetary policy. In response, the Riksbank raised its policy interest rate by 25 basis points to 4.5 percent, and raised its interest rate path forecast - i. e. signaling an upward bias for the near term. The minutes of the policy meeting reveal that some committee members would have preferred to retain a neutral stance, on expectations that the slowing economy will soon start to reduce inflation.

4. The labor force survey for June indicated that employment in persons and hours worked continued to increase year-on-year, but unemployment nevertheless ticked up noticeably, especially for younger workers.

5. Consumer and business confidence both declined in June based on concerns about employment prospects, the continued high energy and food prices, and the slowing external environment.

6. Banking developments. SEB and Swedbank, the dominant Swedish banks in the Baltics, surprised with profits on the upside in the second quarter of 2008. Nevertheless, their loan impairment is rising (from low levels) and funding conditions and market sentiment have weakened over time. Swedbank was downgraded by Moody's, reflecting its large exposure to the slowing regional economies. 


\section{IMF Executive Board Concludes 2008 Article IV Consultation with Sweden}

On August 1, 2008, the Executive Board of the International Monetary Fund (IMF) concluded the Article IV consultation with Sweden. ${ }^{1}$

\section{Background}

A center-right government took office in 2006 and is boosting labor participation and reducing reliance on the welfare state. The government has cut some income taxes and reduced benefit and active labor market programs. It is continuing strong fiscal policies to reduce debt.

Swedish banks have been resilient to global financial turmoil, but risks are rising. Share prices have dropped, and CDS spreads have widened, especially for those banks exposed to the slowing Baltic economies. Vulnerabilities have been mitigated by strong conditions in the Swedish economy, so far, even though Swedish house prices also warrant monitoring.

The economy has performed well, but is sensitive to global demand and activity is now moderating. Exports have benefited from sound competitiveness, but euro-area and US slowing is causing them to decelerate. Private consumption growth has been relatively smooth, as employment and wages have picked up, and disposable income further benefited from tax cuts. Investment expanded rapidly in recent years, as capacity tightened and supported by a

\footnotetext{
${ }^{1}$ Under Article IV of the IMF's Articles of Agreement, the IMF holds bilateral discussions with members, usually every year. A staff team visits the country, collects economic and financial information, and discusses with officials the country's economic developments and policies. On return to headquarters, the staff prepares a report, which forms the basis for discussion by the Executive Board. At the conclusion of the discussion, the Managing Director, as Chairman of the Board, summarizes the views of Executive Directors, and this summary is transmitted to the country's authorities.
} 
competitive krona. Employment growth reached 2 percent, and the unemployment rate declined from 8 percent in 2005 to 6 percent in early 2008.

Tight capacity constraints boosted prices and wages. Inflation increased from $1 / 2$ percent in 2005 to 4 percent in May 2008. Energy and food prices boosted the headline, but the core rate also rose to 2.9 percent. Wages have firmed up, and the Riksbank is monitoring second round effects. Unit Labor Costs (ULC) increased when labor productivity fell at the peak of the labor cycle.

The Riksbank has gradually raised the policy rate to 4.50 percent in July 2008 . Fiscal policy remains strong, and the general government balance is expected to exceed the 1-percent-ofGDP structural surplus rule in the next few years. The 2009 budget, expected this fall, has some policy room to respond to the slowdown.

With strong fiscal adjustment and high private savings, the external current account surplus reached 8 percent of GDP. The trade surplus is 7 percent of GDP, and growing net external assets and favorable returns contributed net factor payments of 2 percent of GDP. Sweden's large foreign aid budget contributes outflows in excess of 1 percent of GDP.

Following global financial turbulence, the economy is expected to slow to 2 percent in 2008 and $13 / 4$ percent in 2009. Risks to growth for 2008 are balanced. Risks for 2009 depend, among other factors, on developments in the banks. If funding costs normalize and the Baltics achieve a soft landing, stable credit expansion should support growth. If turmoil persists, Swedish housing prices fall, or Baltic exposures sour, a credit crunch could slow growth below the forecast. Sweden's long-term outlook appears sound.

\section{Executive Board Assessment}

Executive Directors commended Sweden for its strong economic performance with high output and employment growth, moderate inflation, a well-functioning financial system, solid public finances, and a favorable external position. Directors welcomed that successive authorities have addressed demographic challenges, first with pension reform and now with labor supply measures. Although subject to some uncertainty, Sweden's economic prospects are promising, provided that the financial and economic risks are managed carefully. The main challenges ahead are to continue to strengthen the financial system's resilience to adverse shocks and to firmly anchor inflation expectations.

Directors emphasized that the Swedish financial sector is performing well and that its financial indicators appear to be sound. They stressed the increasing importance of financial-real economy linkages, with the financial turbulence showing that markets react to dents in confidence with high speed and increasing costs that can lower growth. This adds a premium to sound bank management, supervision, and regulation. Swedish banks' strategy of diversifying into Baltic neighbors offers opportunities, but also requires tight risk management to minimize contingent claims.

Directors noted that market signals were indicating that banking risks have increased. While rating agencies, the Riksbank, the Financial Supervisory Authority (FSA), and the banks 
themselves are confident that they are able to cope with adverse events, Directors pointed out that increased interconnectedness in financial systems could accentuate the impact of shocks and spillovers. They encouraged the authorities to complete the draft law on a new banking resolution framework as soon as possible, and recommended that it be applied in a comprehensive manner. Directors welcomed the meaningful progress made by the authorities in addressing the 2002 Financial Sector Asesment Program (FSAP) recommendations, and agreed that an FSAP Update could help identify the policies and measures needed to bolster further financial sector resilience.

Directors considered that the current position of the krona provides Sweden with strong competitiveness, and noted the staff's assessment that the krona is somewhat below its estimated medium-term equilibrium value. With the krona likely to appreciate gradually over the medium term, the current account surplus should decline toward a level consistent with medium-term fundamentals. A firmer krona would also assist in mitigating foreign price pressures.

Directors welcomed the Riksbank's recent increase in the policy rate, given that inflation has risen well above the upper limit of the target band, and indicators of core inflation and inflation expectations had picked up. As short-term price pressures should not be allowed to seep into second-round effects, Directors stressed that monetary policy should remain as firm as needed to clearly break inflation expectations, and welcomed the upward bias in monetary policy.

Directors commended the authorities for their exemplary fiscal performance, and observed that Sweden now has some fiscal room to respond to a slowdown. Directors considered that the 2009 budget could include some targeted tax cuts and moderate increases in public investment in infrastructure, Research and Development, and pre-schooling to strengthen further long-run supply conditions. They welcomed the authorities' recognition that cautious policies remain warranted, given the possible drop in revenues as the economy slows. Also, tax measures could turn out more costly than expected over time and long-run aging costs remain uncertain.

Directors saw merit in further pursuing the intertemporal public sector balance sheet, which could be included in the Budget Bills, updated on an annual basis. Such a balance sheet would provide additional transparency to the fiscal position and forward-looking strategy, thereby enriching the public debate and informing policy. Periodic independent updates of the estimates of aging costs could also be useful.

Directors welcomed the authorities' continued efforts to pursue structural reforms to increase employment. Supply reforms in labor taxation should increase transparency in the tax and benefit system and reduce compliance costs. Evaluations of the efficacy of the labor supply measures by the authorities and stakeholders are welcome to make sure that these deliver the intended effect.

Directors praised the authorities for the high level of official development assistance, noting that it has exceeded 1 percent of GDP. 
Public Information Notices (PINs) form part of the IMF's efforts to promote transparency of the IMF's views and analysis of economic developments and policies. With the consent of the country (or countries) concerned, PINs are issued after Executive Board discussions of Article IV consultations with member countries, of its surveillance of developments at the regional level, of post-program monitoring, and of ex post assessments of member countries with longer-term program engagements. PINs are also issued after Executive Board discussions of general policy matters, unless otherwise decided by the Executive Board in a particular case. The staff report (use the free Adobe Acrobat Reader to view this pdf file) for the 2008 Article IV Consultation with Sweden is also available. 
Sweden: Selected Economic and Social Indicators

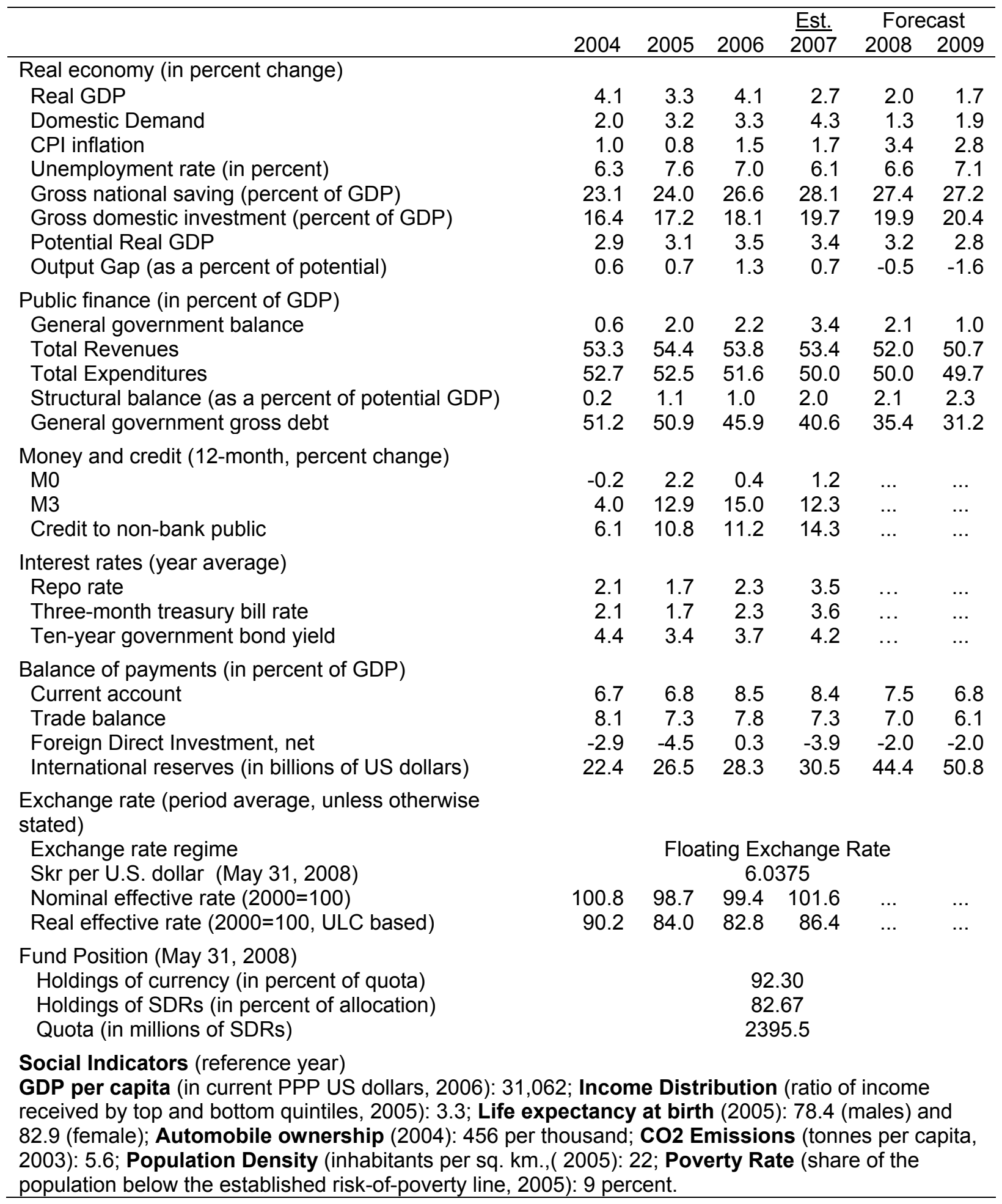

Sources: Statistics Sweden; Riksbank; Ministry of Finance; Datastream; INS; and IMF staff estimates. 


\section{Statement by Jens Olof Henriksson, Executive Director for Sweden August 1, 2008}

First, the Swedish authorities convey their appreciation to staff for constructive discussions in Stockholm, and for a well-drafted report.

\section{Recent Developments}

My authorities broadly agree with staff's overall assessment pointing to sound long-term prospects for the Swedish economy, but with a slowdown in growth in the near-term due to the global financial turbulence and deteriorating confidence. The main differences between staff and my authorities regarding the near-term outlook concern export growth, resource utilisation and inflation, where my authorities have a more optimistic view on the support from global growth and a more pessimistic view on the rate of potential growth.

On the support from global growth, staff's forecast for export growth is below the Swedish authorities' projection for the years 2008-2010, while the forecast for import growth does not differ over the period as a whole. This divergence follows from staff's expectations of an appreciation of the Swedish krona. Overall, compared to the Swedish authorities, the divergence in the outlook for the current account surplus is matched by a divergence in the opposite direction concerning domestic demand growth.

Staff's more optimistic expectations about potential growth in the coming years in turn rest on the idea of a relatively strong ongoing structural recovery following the crisis in the early 1990s. In keeping with this, staff also sees a higher unemployment rate and somewhat lower inflationary pressures in the years ahead than the Swedish authorities.

\section{Financial Sector Surveillance}

My authorities are well aware of certain shortcomings of the possibilities of managing distressed institutions, and agree with the staff report that improvements are needed in the legislative framework for bank resolution. Therefore, a new framework is drafted by the Ministry of Finance. The framework will respond to the issues raised by staff.

However, my authorities disagree with the statement in the staff report that all banks need to be included in the new framework. The assessment by the Ministry of Finance is that the largest risk, from a financial stability and society's need for financial services perspective, comes from corporate bank and credit-market companies that take deposits. Consequently, the number of financial institutions potentially encompassed by the framework could be limited.

The authorities mainly agree with staff's assessment of how a crisis management framework should function, and the new framework will include all the tools described in the staff report, except for redemption of shares, which is viewed as redundant in this framework. 
My authorities also agree that it is important that the supervisory authority has adequate resources. The Swedish FSA has continuously been given increased resources from the Government during the past years. For 2008 the resources were increased with more than 10 percent. It is, however, also important that the supervisory authority has the right focus. The Government is, therefore, planning a review of the operations of the Swedish FSA in order to prioritize future activities in this field.

The FSA plays, indeed, an important role in the initial stages of a bank crisis situation, and also in the continued supervision of the bank subject to authority measures. However, should the FSA handle all issues related to crisis management, its independence could be questioned. Consequently, according to the drafted framework, a new designated authority will be responsible for managing bank crisis resolutions.

The banks' lending to corporates and households in the Baltic countries continues to be a cause of concern. The Baltic activities account for a considerable part of the total earnings and lending for Swedish banks. This makes banks vulnerable to the economic development of these countries.

\section{Exchange Rate Surveillance}

Since, as noted by staff, the krona is floating freely and thus determined by market forces, there are no clear policy conclusions to be drawn from exchange rate analyses in the Swedish case. Given the established lack of short-term predictive power of equilibrium exchange rate valuation models, it is also of limited interest as far as forecasting is concerned. However, this does not imply a disregard for exchange rate considerations in the Riksbank's monetary policy decisions. On the contrary, the recent tightening of monetary policy and the upward revisions of the Riksbank's own policy rate forecasts were partially based on the assumption that foreign price increases will have a smaller effect on the price level in Sweden if monetary policy lends additional strength to the krona.

\section{Monetary Policy}

Staff raises concerns over the pace of policy rate normalization during the 2003-2007 period, citing deviations from Taylor and other simple inflation targeting rules. However, given the inflation target, and the low inflation and inflation expectations figures, reported at the time, as well as relatively low levels of resource utilisation indicated by various negative output gap measures during most of the period, there was little scope for tighter monetary conditions. The inflationary pressures that eventually arose were primarily due to unexpected developments in the world markets for food and energy, rather than domestic capacity constraints. In this context, the link between low real interest rates and asset price increases noted by staff is uncontroversial, but not necessarily a reason to accept persistent deviations from the inflation target. 
That aside, differences between the actual policy rates and benchmarks provided by simple rules should be interpreted with great care, especially since the prescriptions of the rules are highly sensitive to the choices of weights, measures of inflation expectations and what amounts to a normal policy rate.

On monetary policy in the period ahead, the Riksbank's July 2008 monetary policy report reveals that it has drawn the same conclusions as staff about the need for a repo rate path which is somewhat above the long-term neutral level, and thus, can forestall possible second round effects of the current inflationary pressures from the food and energy sectors.

Since the previous Article IV consultation, the Riksbank has started publishing its own policy rate path forecasts with a three-year horizon, intended to yield benefits in terms of clarity of message and a better understanding of the dynamic nature of monetary policy considerations. Predictability is also likely to be enhanced by the introduction of attributed comments and positions of individual governors in the published minutes of monetary policy meetings. Since last year, the Riksbank has also doubled the frequency of its reporting of key economic indicators and forecasts supporting its monetary policy decisions to six times per year. In the end, it is hoped that these improvements will make it easier to understand the Riksbank's decisions, including the small differences that it may have with the Fund.

In conjunction with discussions about the combined effects of fiscal and monetary policies, it is worth noting that the far-reaching policy independence of the Riksbank, as well as established traditions, precludes any explicit policy coordination between the monetary and fiscal authorities. This makes the expression "policy mix" somewhat unfortunate as it may give a different impression.

\section{Fiscal Policy}

My authorities have the opinion that the description and recommendations as regards fiscal policy lack nuances and insight that is present elsewhere in the report. Appropriate fiscal policy in the future is a function both of short-run macro developments and needs to be related to long-run outlook including demographic changes.

Staff points out that the framework "requires cyclical dating and is not fully anchored in the long-run analysis". Cyclical dating is unavoidable, not a flaw of the framework, and it is true that we need to improve long-run analysis and this is currently done. It is also worth mentioning that Sweden's fiscal position is relatively good compared to other EU-countries.

According to staff there is a risk for accommodative fiscal policy in light of the sizeable surplus. The government's overriding political target is enhancing employment. The policy rests with a responsible economic policy and strong public finances. Strong public finances create a demand for additional spending. The government is well aware of this risk and has among other things initiated a fiscal policy council to conduct independent evaluations of the 
Swedish Government's fiscal policy. However, the fiscal framework with the expenditure ceiling, set three years ahead, should imply that this risk is fairly small.

Staff also mentions a number of potential concerns regarding fiscal policy. For example they point out that the earned income deduction may be costly. Estimates of long-run effects made by the government, and others, suggest sizeable effects on employment and unemployment. The very high income taxes in Sweden make sizeable employment effects more likely than in many other countries. The increased labor supply increases tax revenues, as well as diminishes benefit expenditures. It is also worth mentioning that entitlement cuts also have effects on labor supply.

The costs related to the tax credit for household services have so far been smaller than expected. And as with other tax expenditures these are continuously monitored.

Nonetheless, the authorities concur with staff that it is important to further analyze the differences in the estimates of the ageing costs, and this should be done by the government itself, as well as by other independent bodies, e.g. the fiscal policy council. My authorities agree that the long-run sustainability is by far the most important issue. In order to estimate the effects on the public finances of an ageing population, the government has strengthened its efforts as a part of their overhaul of their fiscal framework, to improve and develop the basic data and the long-run scenario calculations.

The government also agrees with staff's recommendation to limit the targeted programs to benefit transparency in the tax and benefit system. It should be noted, however, that the targeted measures have been important in reducing the number of people being outside the labor market. General vis-à-vis targeted measures are also a question about limited resources. Even if the general rate of unemployment is quite low in Sweden compared to many other countries, employment rates differ greatly for different groups in Sweden. For example, the rate of unemployment is substantially higher for young, elderly and immigrants.

In addition staff recommends an intertemporal public sector balance sheet in the Budget Bills, updated on an annual basis. My authorities agree that this would be valuable, and plans to add such information to the extent possible. The need to develop such analysis must, however, be considered vis-à-vis the need for other improvements of long-run analysis, e.g. long-run analysis related to ageing.

The staff report also implies that the local governments have little independent financing. My authorities would argue that the autonomy for local governments is sizeable as regards taxation and many expenditure types, though the local governments are dependant on grants from the central government. The tax base is set by the central government, but the local governments have full control over the tax rate. The independence is also obvious on the expenditures side where local governments apply different priorities. The most important 
restriction is the balance constraint, which requires that if a local government runs a deficit they are obliged to restore the deficit within three years.

\section{Final Note}

I look forward to conveying the outcome of the Board discussion to the Swedish authorities. This will complete the constructive dialogue in which they have been involved with the Fund's staff during this consultation. On behalf of the Swedish authorities, I also look forward to a fruitful cooperation in the years to come. The authorities intend to authorize publication of the staff report, in accordance with normal Fund procedures. 